九州大学学術情報リポジトリ

Kyushu University Institutional Repository

Some Miocene Plant Fossils from Tottori and Shimane Prefectures, San-in District

Hojo, Yoshio

https://doi.org/10.5109/1544154

出版情報：九州大學理學部紀要：Series D, Geology. 22 (1)，pp.13-35，1973-11-15. Faculty of Science, Kyushu University バージョン :

権利関係 : 
Mem. Fac. Sci., Kyushu Univ., Ser. D, Geol., Vol. XXII, No. 1, pp. 13-35, figs. 1-4, tables 1-4, pls. 4-10, November 15, 1973

\title{
Some Miocene Plant Fossils from Tottori and Shimane Prefectures, San-in District
}

\author{
Yoshio HOJO
}

\begin{abstract}
The Miocene sediments in San-in district have been studied mostly from the geological and geostructural standpoint, resulting in that little is known of paleontological information on the fossil floras contained in the Miocene. The present paper deals only with the paleobotanical description on the samples collected from three separate areas, which will be a good addition to meager knowledge of the Miocene floras in the San-in district. Geological and structural consideration on the Miocene formations will be given in another paper.
\end{abstract}

\section{Introduction and Acknowledgements}

The Miocene formations distributed sporadically in San-in district have been investigated many geologists, whose subjects were focused mostly on the stratigraphy and geological structures (MURAYAMA et al., 1963; NishIYAMA and MIURA, 1963; Tottori Prefecture, 1966). Although some of fossil floras were listed up in the previous works, few paleontological studies have been carried out on fossil floras contained in the Miocene sediments.

During the graduate course at Kyushu University, I collected a fairly large number of fossil plants from several localities in this district and carried out paleobotanical study. The present work is based on these specimens together with those added by later field works. Although the present paper gives only a paleobotanical description of some interesting and important species, it is a good addition to still meager paleobotanical information on the fossil plants in the San-in district. Geological and paleontological discussion derived from the present study will be given in another paper.

I express my sincere gratitude to Professor Emeritus Hisamichi Matsushita of Kyushu University for his continuous encouragement through the present works. I express my hearty thanks to Prof. Ryuzo ToRIYama, Prof. Ryohei TAKaHASHI of the Department of Geology, Kyushu University and Prof. Jyonosuke OHARA of the College of General Education of the same university, who gave me helpful suggestions and read over the manuscript. Acknowledgements are also due to Prof. Hideo URATA of the College of General Education, Kyushu University, Prof. Kiyoshi Takahashi of Nagasaki University, and Prof. Toshimasa TANAI of Hokkaido University for their helpful advices on the determination of fossil specimens. 


\section{Occurrence of the plant fossils}

The main localities, wherefrom the specimens were collected, are as follows (Figs. 1, 2) :

1) Area-A. Near Tottori City, Tottori Prefecture.

Loc. 1. Tochimoto, where a fine cut is found at the northern corner of the yard of the temple Fuganji. The cutting consists mainly of massive black mudstone, in which a lot of plant fossils is contained.

Loc. 2. Okamasu: At the western side of the yard of an unnamed villagetemple near Goryosankochi, a cliff is located, being composed mainly of mudstone, and where well preserved fossil plants are obtained.

Loc. 3. Miyanoshita: Near Uba-jinjya a cliff is met with, where medium grained sandstones intercalating thin layers of mudstone and tuffite are quite well exposed. Fossil plants are contained both in sandstone and mudstone.

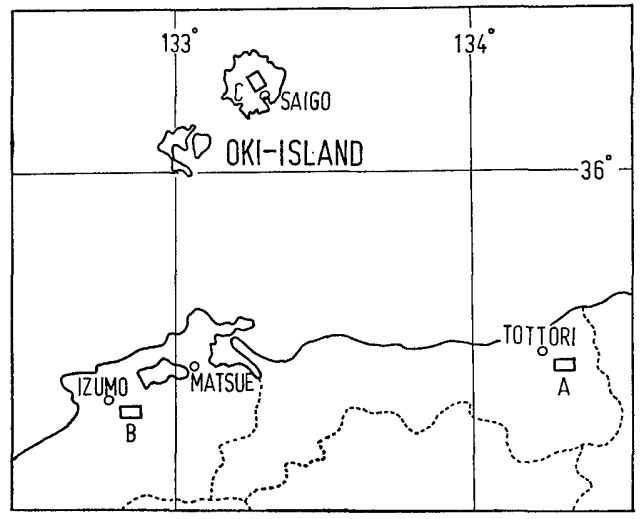

Fig. 1. Index map of three separated areas Area-A. Near Tottori-city

Area-B. In Takakubo lignite field Area-C. In Oki-island

A

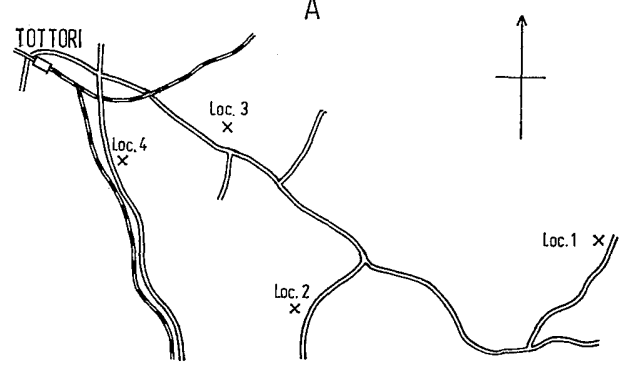

B

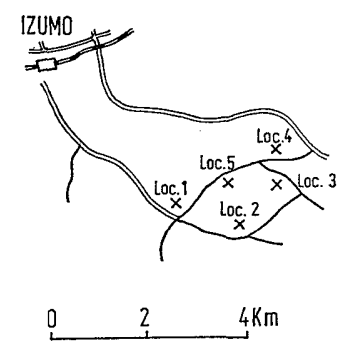

C

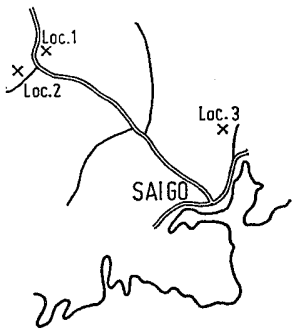

Fig. 2. Fossil localities in three separated areas.

A. Near Tottori-city

B. In Takakubo lignite field

C. In Oki-island 
Table 1. Stratigraphical table

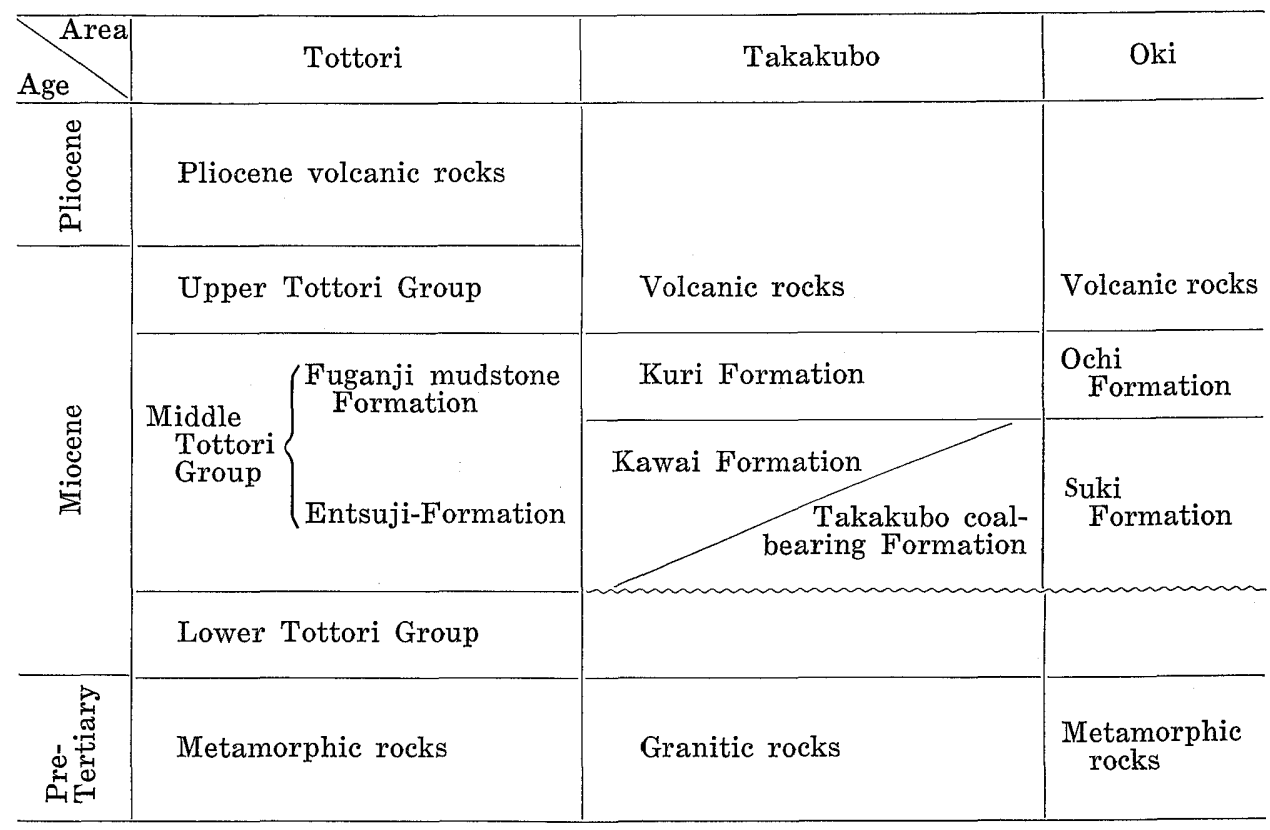

Loc. 4. Kumoyama: There is a cliff in the northern margin of the yard of a temple. It consists mainly of massive mudstone including fossil leaves.

In this area, plant fossils are mainly contained in mudstone of the Fuganji mudstone Formation, Tottori Group. The stratigraphic sequence in this area is shown in Table 1. At Loc. 1, the fossil materials, in which the leaves of Comptonia are abundant, are found in massive black mudstone. At Loc. 2, the Fuganji mudstone Formation is mainly composed of laminated mudstone, in which several thin layers of fine grained sandstone and tuff are intercalated. While fossil leaves are well preserved in mudstone, they are mostly fragmental in sandstone and tuff layers. At Loc. 3, medium grained sandstone bearing thin layers of mudstone and tuff are well exposed, and fossil materials consisting mainly of leaf-impressions are included in the thin layers of mudstone. Both in sandstone and thin layers of tuff, the fragmental leaves and branches are remarkably found. At Loc. 4, fossil leaves are abundantly included in massive mudstone. In the fossil assemblage obtained from this area Alangiaceae, Ulmaceae, Betulaceae, Taxodiaceae and Fagaceae are predominant.

2) Area-B. In the Takakubo lignite field, Shimane Prefecture.

Loc. 1. Tsunodani: Both from small exposures and a cutting along the road from Tsunodani to Okitani, a lot of fossil plants is obtained.

Loc. 2. Misaka: Along the road from Misaka to Tsunodani, there is a fair cliff composed of alternation of sandstone and shale.

Loc. 3. Takakubo: Several cuttings are met with along the road from Takakubo to Nishitani. As at the marked place tuffaceous sandstone and shale contain plant remains, this may be one of expedient 
localities for collecting fossils.

Loc. 4. Nishitani: Tuffaceous sandstone and shale make a cliff by the road to Okitani. It is really a nice locality for collection of plant fossils.

Loc. 5. Okitani: The cut facing to the road to Tsunodani is composed of alternation of sandstone and shale, dark brown shale and pale brown coarse grained sandstone. From brown shale fossil leaves and their fragments are obtained.

In this lignite field, plant fossils are preserved in the Takakubo coal-bearing Formation; its stratigraphic sequence is shown in Table 1. Although the lithofacies of this formation varies both laterally and vertically, it is generally divided into the following six members in ascending order.
a) Liparitic tuff
b) Pebble-bearing coarse grained sandstone
c) Tuffaceous sandstone and shale
d) Pale brown coarse grained sandstone
e) Alternation of sandstone and shale
f) Dark brown shale

At Locs. 1, 3 and 4, tuffaceous sandstone and shale are well exposed, and several thin layers of coal are intercalated in shaly part. In shale beds above and below these coal seams, fossil leaves and fragments of silicified woods are abundantly contained. At Loc. 2, plant fossils are preserved in shaly part of the alternation of sandstone and shale. At Loc. 5, fossil leaves and their fragments are obtained from the dark brown shale in the uppermost member of this coal-bearing formation.

In the fossil assemblage obtained from this area Fagaceae, Myricaceae, Taxodiaceae, Ulmaceae, and Lauraceae are plentiful.

3) Area-C. In Oki-island, Shimane Prefecture

Loc. 1. The cliff along the road through the Nakayama to highest point.

Loc. 2. The cliff standing by the road for forestry near Loc. 1.

Loc. 3. Gongenbara, where a cut is made by the road to Togo-cho and displays a good locality for collection of sample.

The Miocene sediment in this island is mainly distributed along the Yatsuo river, of which the lower part is called the Suki Formation and the upper the Ochi Formation.

At Locs. 1 and 2, the pebble-bearing sandstone and siliceous shale of the Suki Formation are well exposed, and plant fossils are included in the siliceous shale. Along the road for forestry, a lot of fragments of fossil leaves are found in brown mudstone, but they are not sufficient to examine for their broken forms. Of the fossil materials obtained from these localities, the leaves of Alnus, Carpinus and Juglans are abundant. At Loc. 3, the Ochi Formation is mainly composed of tuff, tuffaceous shale and sandstone in ascending order. While a lot of fragments of fossil leaves is observed in tuffaceous shale, well preserved leaves are obtained from tuffaceous sandstone.

Of the fossil leaves from this area, the leaves of Comptonia make up a greater number. 


\section{Note on the assemblage of fossil plants}

In the foregoing sections, predominant representatives in respective localities in three areas briefly commented. The fossil species identified with certainty and their living equivalents are listed up in Table 2, 3 and 4. To provide a lucid description, these fossil assemblages are called the Fuganji-, Takakubo-, and Dogo-floras in this paper.

In the Fuganji flora, some of the living equivalents of fossil species, such as Quercus accutissima, Q. variabilis, Castanea mollissima, and Alangium chinense, are also known far in Central and South China. It is also remarkable that Carya cathayensis, Liquidamber formosana, Entada formosana, and Wistaria floribunda, which are now limited in growth only in Formosa and South China, are considered to be the equivalents of some of the Fuganji flora, although they are smaller in number in the assemblage.

Of the living equivalents of Takakubo flora, Metasequoia glyptostroboides, Glyptostrobus pencilis, Salix wilsoni, Quercus variabilis, Ulmus lancaefolia, and Alangium chinese are distributed at present only in China, and futhermore, Quercus stenophylla and Entada formosana in Ryukyu Island and Formosa.

Most of the living equivalents of these two floras, Fuganji and Takakubo,

Table 2. Fossil species and their living equivalents of the Fuganji flora

\begin{tabular}{l|l}
\hline \multicolumn{1}{c|}{ Fossil species } & \multicolumn{1}{|c}{ Living equivalents } \\
\hline Metasequoia occidentalis & M. glyptostroboides \\
Salix sp. (1) & S. jessoensis \\
S. sp. (2) & S. sachalinensis \\
Comptonia naumanni] & C. asplenifolia \\
Juglans japonica & J. sieboldiana \\
Carya sp. & C. cathayensis \\
Pterocarya nipponica & P. rhoifolia \\
Alnus sp. & A. pendula \\
Betula cf. nipponica & B. grossa \\
Carpinus miocenica & C. laxiflora \\
C. cf. stenophylla & C. carpinoides \\
C. subcordata & C. cordata \\
Quercus sinomiocenicum & Q. accutissima \\
Q. sp. & Q. variabilis \\
Castanea ungeri & C. mollissima \\
Ulmus protojaponica & U. japonica \\
Zelkova ungeri & Z. serrata \\
Lindera sp. & L. umbellata \\
Neolitsea sp. & N. serica \\
Liquidamber miocenica & L. formosana \\
Entada cf. mioformosana & E. formosana \\
Wistaria sp. & W. floribunda \\
Acer protojaponicum & Acer japonicum \\
Tilia sp. & T. miqueliana \\
Alangium aequalifolium & A. chinense \\
&
\end{tabular}


Table 3. Fossil species and their living equivalents of the Takakubo flora

\begin{tabular}{l|l}
\multicolumn{1}{c|}{ Fossil species } & \multicolumn{1}{|c}{ Living equivalents } \\
\hline Picea cf. kaneharai & P. polita \\
Metasequoia occidentalis & M. glyptostroboides \\
Glyptostrobus europaeus & G. pencilis \\
Fokienia notoensis & F. kawaii \\
Salix cf. lavateri & S. wilsoni \\
Comptonia naumanni & C. asplenifolia \\
Juglans sp. & J. sieboldiana \\
Quercus mandraliscae & $Q$. stenophylla \\
Q. nathorsti & Q. glauca \\
Q. cf. sinomiocenicum & Q. accutissina \\
Carpinus shimizui & C. orientalis \\
Ulmus longifolia & U. lancaefolia \\
Zelkova ungeri & Z. serrata \\
Lindera gaudini & L. glauca \\
Machilus cf. ugoana & M. japonica \\
Liquidamber miocenica & L. formosana \\
Entada cf. mioformosana & E. formosana \\
Acer subpictum & A. mono \\
Alangium koyamae & A. chinense \\
&
\end{tabular}

Table 4. Fossil species and their living equivalents of the Dogo flora

\begin{tabular}{l|l}
\multicolumn{1}{c|}{ Fossil species } & \multicolumn{1}{|c}{ Living equivalents } \\
\hline Metasequoia occidentalis & $M$. glyptostroboides \\
Comptonia naumanni & C. asplenifolia \\
Juglans japonica & J. ailanthifolia \\
Carpinus miocenica & C. laxiflora \\
Alnus miojaponica & A. japonica \\
Machilus ugoana & M. japonica \\
Acer florini & A. mono
\end{tabular}

are deciduous trees, being found today in mountaineous high-land of warm region in Asia.

Enough information has not been available from the Dogo flora to determine its characteristics with certainty, because it is not large in number of component species. However, the general feature of the Dogo flora may be outlined by the specific assemblage with its living equivalents. It is concluded that the Dogo flora is almost the same in the characteristics of floral assemblage with those of other two floras.

Based on the general characteristics of floral assemblage, the three floras mentioned above are, as a whole, comparable with the Daijima-type flora in Northeast Japan. It is, therefore, hard to discriminate these three floras from each other. However, it remained a problem whether they are really the same. To settle this problem, it seems necessary to take the geographical distribution of the living equivalents of the fossil floras into consideration (Fig. 3). 


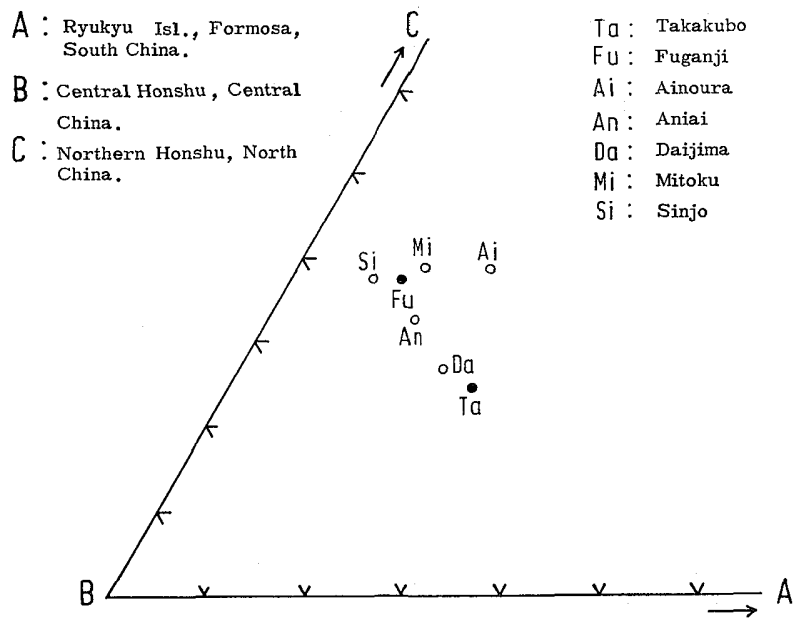

Fig. 3. Diagram of the distribution of living equivalents of the typical Miocene floras and the present fossil floras of Fuganji and Takakubo.

Considering the geographical distribution of the living equivalents of the Miocene fossil species of Japan, the following three areas can be depicted; (A)Ryukyu Islands, Formasa and South China; (B)-Central Honshu and Central China; (C)-Northern Honshu and North China.

The living equivalents of the Takakubo flora are distributed in (A)-(B), really warm-subtropical area, that is the same with the Daijima-type flora. On the other hand, the living equivalents of the Fuganji flora grow in $(B) \sim(C)$ area, although they comprise several species of warmer type, suggesting warmer climatic condition.

So far as the geographical distribution of living equivalents is concerned, it is consequently assumed that the Fuganji flora does not correspond to the Takakubo, but to the Aniai-, Mitoku-, and Shinjo-type floras. This assumption may be well supported by stratigraphic relationship of the fossil-bearing formation in the two areas under consideration-Takakubo and Fuganji. I am, therefore, inclined to consider that the Takakubo flora is a little older than the Fuganji. Any definite conclusion is not given to the Dogo flora because of the insufficiency of material.

\section{Palaeobotanical Descriptions}

Family PinNACEAE

Picea cf. kaneharai TANAI et ONOE

Pl. 4, Fig. 1

Compare:

1961. Picea kaneharai TANAI et ONOE. Geol. Surv. Japan, Rep. no. 187, p. 17, Pl. 1, fig. 9. 
Material: Winged seed.

Remarks: The present specimen has some resemblance to Picea kaneharai in general characters. This species was originally described from the Early Pliocene Ningyo-toge Formation in Tottori and Okayama Prefectures. Picea kaneharai is closely similar to the modern Picea polita CARR., which is distributed in the mountains of central Honshu, Shikoku and Kyushu.

Occurrence: Takakubo coal-bearing Formation; Loc. no. 4, Takakubo Area.

\author{
Family TAXodiaceae \\ Sequoia sp. \\ Pl. 4, Figs. 3, 4
}

Material: Foliage shoots.

Remarks: Although the present materials are fragmental, they are identical to the genus Sequoia by foliage features. In the Takakubo coal-bearing Formation the fragmental foliage of Taxodiaceae are abundantly found.

Occurrence: Takakubo coal-bearing Formation; Loc. nos. 1, 3 and 5, Takakubo Area.

\title{
Metasequoia occidentalis (NEWBERRY) CHANEY \\ Pl. 4, Figs. 2, 5-9
}

1951. Metasequoia occidentalis (NewbWrry) Chaney. Trans. Amer. Philosoph. Soc., N. S. Vol. 40, p. 225, many figures.

1961. Metasequoia occidentalis, TANAI. Jour. Fac. Sci. Hokkaido Univ. Ser. 4, Vol. 11, pp. 263-264, Pl. 3, figs. 1-3, 5-8, 14.

1963. Metasequoia occidentalis, TANAI and SUzUKI. Tertiary floras of Japan, p. 104, Pl. 2, figs. 5-7.

1963. Metasequoia occidentalis, Huzioka. Tertiary floras of Japan, pp. 188-189, Pl. 28, fig. 12.

Material: Foliage shoots and cones.

Remarks: The present specimens are safely referred to this species by their main features of foliage shoot and cone. The present foliage shoots are obtained from the Fuganji mudstone Formation and the cones are from the Suki Formation in Oki-island.

Occurrence: Suki and Fuganji mudstone Formations; Loc. nos. 1 and 2, Dogo Area; Loc. nos. 2 and 3, Tottori Area.

\section{Family CuPREsSACEAE}

\section{Fokienia notoensis Matsuo}

Pl. 4, Figs. 10, 11

1963. Fokienia notoensis Matsuo. Tertiary floras of Japan, pp. 233-234, Pl. 44, figs. 1-4.

1963. Fokienia notoensis, Huzioza. Tertiary floras of Japan, pp. 189-190, Pl. 28, figs. 16-18a. 
Material: Foliage branches and branchlets.

Remarks: The present materials are identified with certainty with Fokienia notoensis MATSUo which closely resembles the living $F$. kawaii HAYATA of south China and Formosa.

Occurrence: Takakubo coal-bearing Formation; Loc. no. 4, Takakubo Area.

\section{Family SALICACEAE}

Salix cf. lavateri HEER

Pl. 5, Fig. 1

Material: Leaf.

Description: Although all the leaf is lacking in base and opex, it shows linear-elongated shape, $2.3 \mathrm{~cm}$ in width. Margin finely serrate, midrib stout, secondary veins slightly curved ascendingly.

Remarks: Although the present specimen is incomplete, it has some characters like those of Salix lavateri, which was originally described by NATHORST in 1888.

Occurrence: Takakubo coal-bearing Formation; Loc. no. 4, Takakubo Area.

\section{Salix sp.}

Pl. 4, Fig. 26

Material: Leaf.

Remartss: Several leaf characters of this material, excepting the leaf-size, are similar to Salix masamunei Matsuo (Matsuo, 1963, pp. 234-235, pl. 46, fig. 6) from the Miocene Notonakajima flora.

Occurrence: Suki Formation; Loc. no. 1, Dogo Area.

\section{Family MYrICACEAE}

\section{Comptonia naumanni (NATH.) HUZIOKA}

Pl. 4, Figs. 12-25; Pl. 5, Fig. 13

1961. Comptonia naumanni (NATH.) Huzioka. Jour. Min. Coll. Akita Univ. Ser. $A$, Vol. 1, p. 65, Pl. 3, figs. 7, 8 .

1963. Comptonia naumanni, TANaI and Suzukr. Tertiary floras of Japan, p. 108, Pl. 3, figs. 5-8; HuzioKa, p. 191, Pl. 29. figs. 4, 5; MAtsuo, p. 235, Pl. 47, figs. 1a, 2.

Material: Leaves.

Remarks: This species is commonly found in the Middle Miocene floras of Japan, and is a representative of the Daijima-type flora. Although the present materials are variable in size and some of them look like Comptonia nipponica ENDO in the shape of lamina, they are safely assigned to C. naumanni based on HuzIoKA's description. This species is closely related to the living Comptonia peregrina (L.) CoulT (C. saplenifolia L.) of eastern North America, whose leaves are not always dissected down to the midvein. 
Occurrence: Fuganji mudstone Formation; Loc. no. 1, Tottori Area: Takakubo coal-bearing Formation; Loc. no. 4, Takakubo Area: Ochi Formation; Loc. no. 3, Dogo Area.

\section{Family JUGLANDACEAE \\ Juglans japonica TANAI \\ P1. 5, Figs. 2-5, 8}

1961. Juglans japonica TANAI. Jour. Fac. Sci. Hokkaido Univ., Ser. 4, Vol. 11, p. 275, Pl. 6, figs. 9, 10 .

Material: Leaves.

Remarks: The present specimens are incomplete, but they are able to be identified with this species on the basis of leaf-outline and nervation. The leaves of this species resemble those of the living Juglans ailanthifolia CARR. of Japan.

Occurrence: Suki Formation; Loc. nos. 1 and 2, Dogo Area.

\section{Juglans sp.}

Pl. 6, Fig. 2

Material: Leaf.

Remarks: Although the specimen is incomplete, it belongs surely to this genus on the basis of the marginal serration and leaf-outline.

Occurrence: Fuganji mudstone Formation; Loc. no. 2, Tottori Area.

\section{Explanation of Plate 4}

(All figures in natural size)

Fig. 1. Picea cf. kaneharai TANAI et ONOE. .................................... 19 Takakubo Area, Loc. no. 4.

Figs. 2, 7. Metasequoia occidentalis (Newberry) Chaney. ................ 20 Dogo Area, Fig. 2, Loc. no. 2; Fig. 7, Loc. no. 1.

Figs. 3, 4. Sequoia sp. ......................................... 20 Takakubo Area, Loc. no. 1.

Figs. 5, 6, 8, 9. Metasequoia occidentalis (Newberry) Chaney. ...........Page 20 Tottori Area, Figs. 5, 6, Loc. no. 2; Figs. 8, 9, Loc. no. 3.

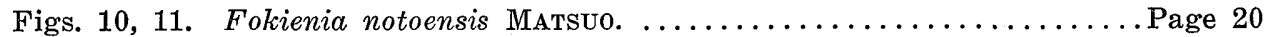
Takakubo Area, Loc. no. 4.

Figs. 12, 14, 21, 24. Comptonia naumanni (Nath.) Huzioka. ............. Page 21 Dogo Area, Loc. no. 3.

Figs. 13, 16, 19, 20, 23, 25. Comptonia naumanni (NATH.) HuZiokA. ......Page 21 Takakubo Area, Loc. no. 4.

Figs. 15, 17, 18, 22. Comptonia naumanni (Nath.) Huzioka. ............Page 21 Tottori Area, Loc. no. 1.

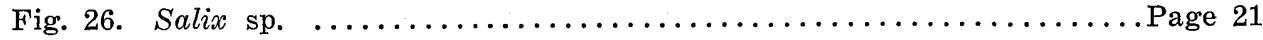

Dogo Area, Loc. no. 1. 


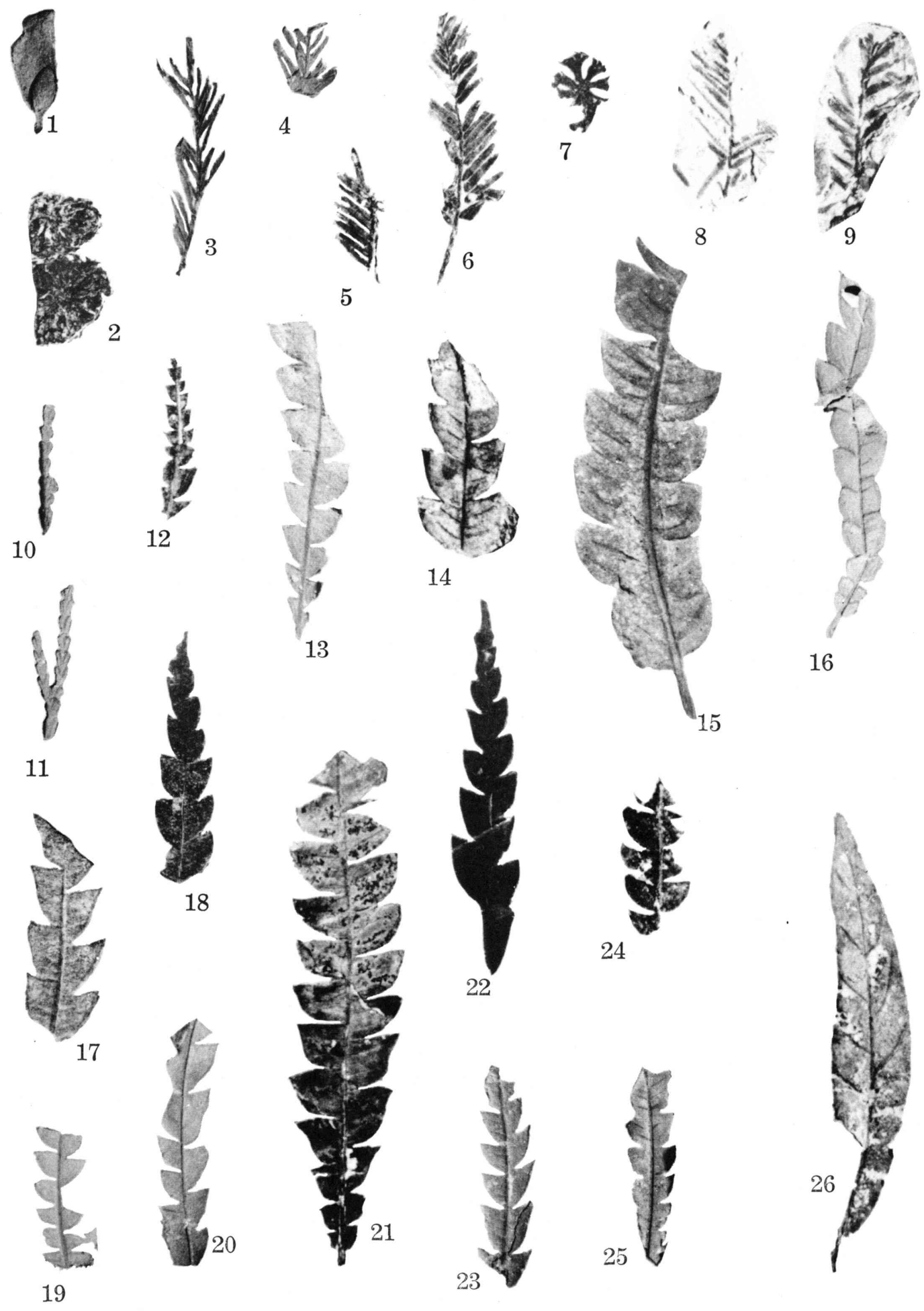

Y. HoJo: Some Miocene plant fossils from Tottori and Shimane Prefectures 

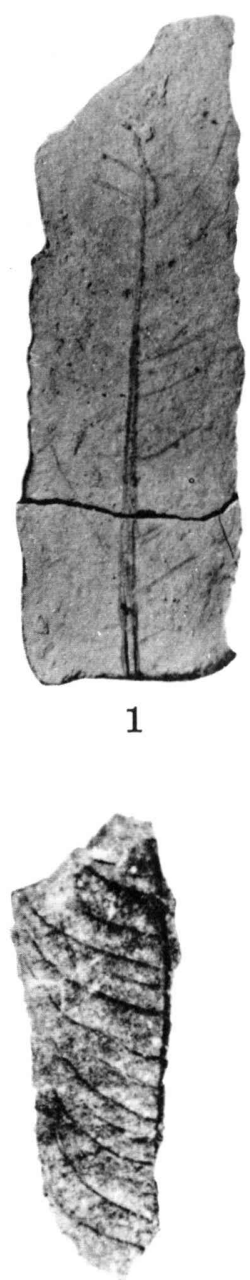

5

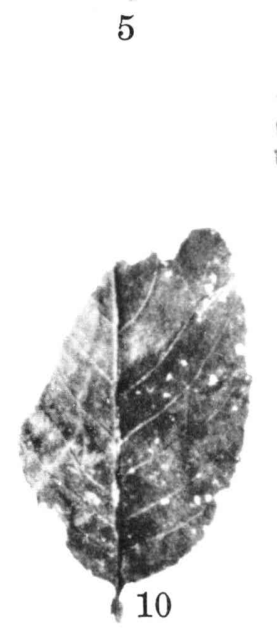

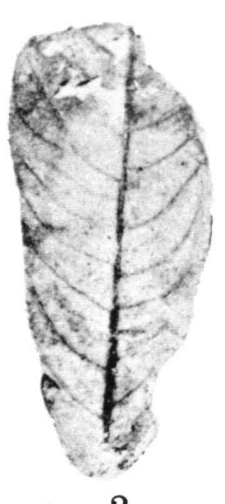

2
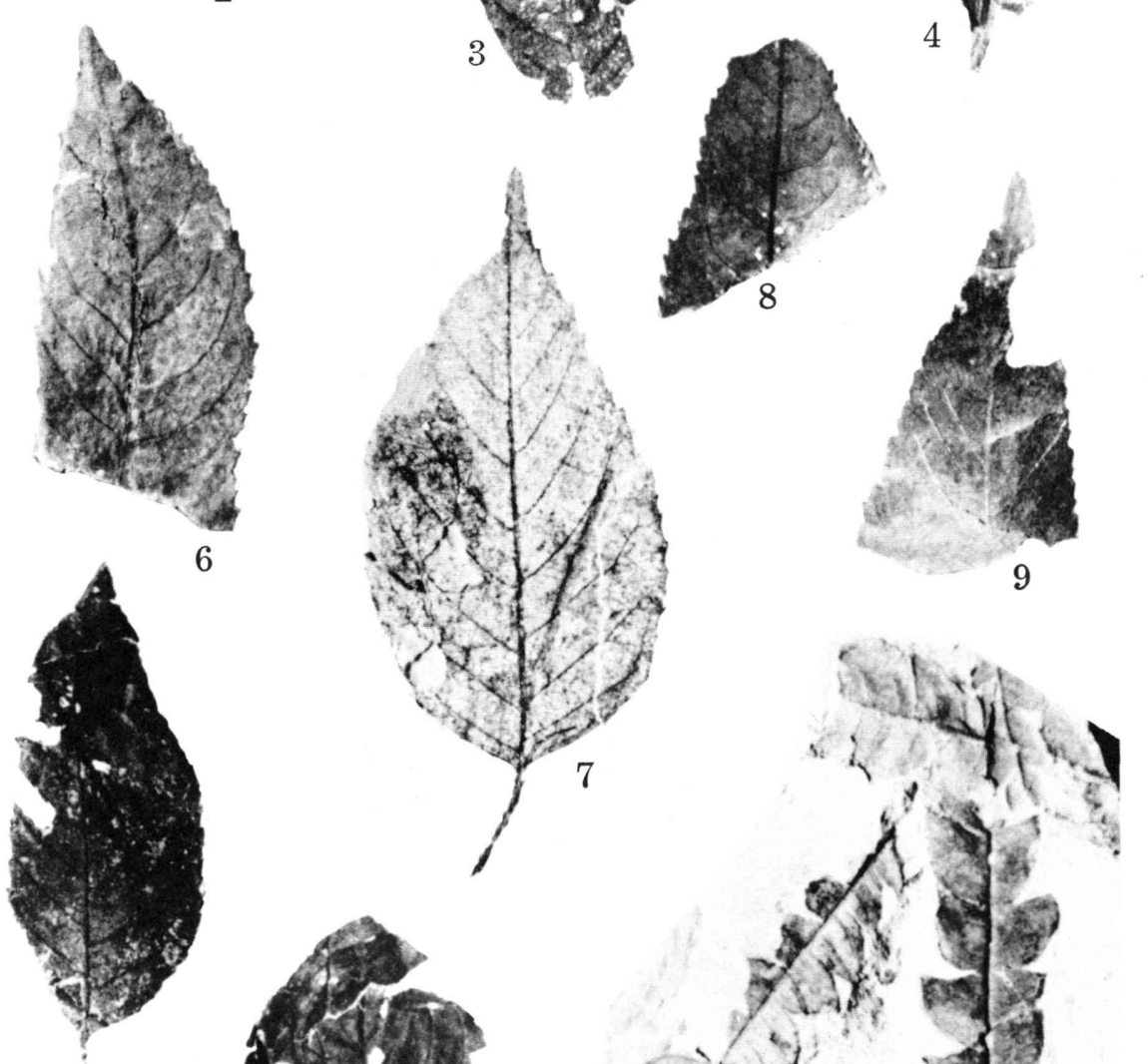

11
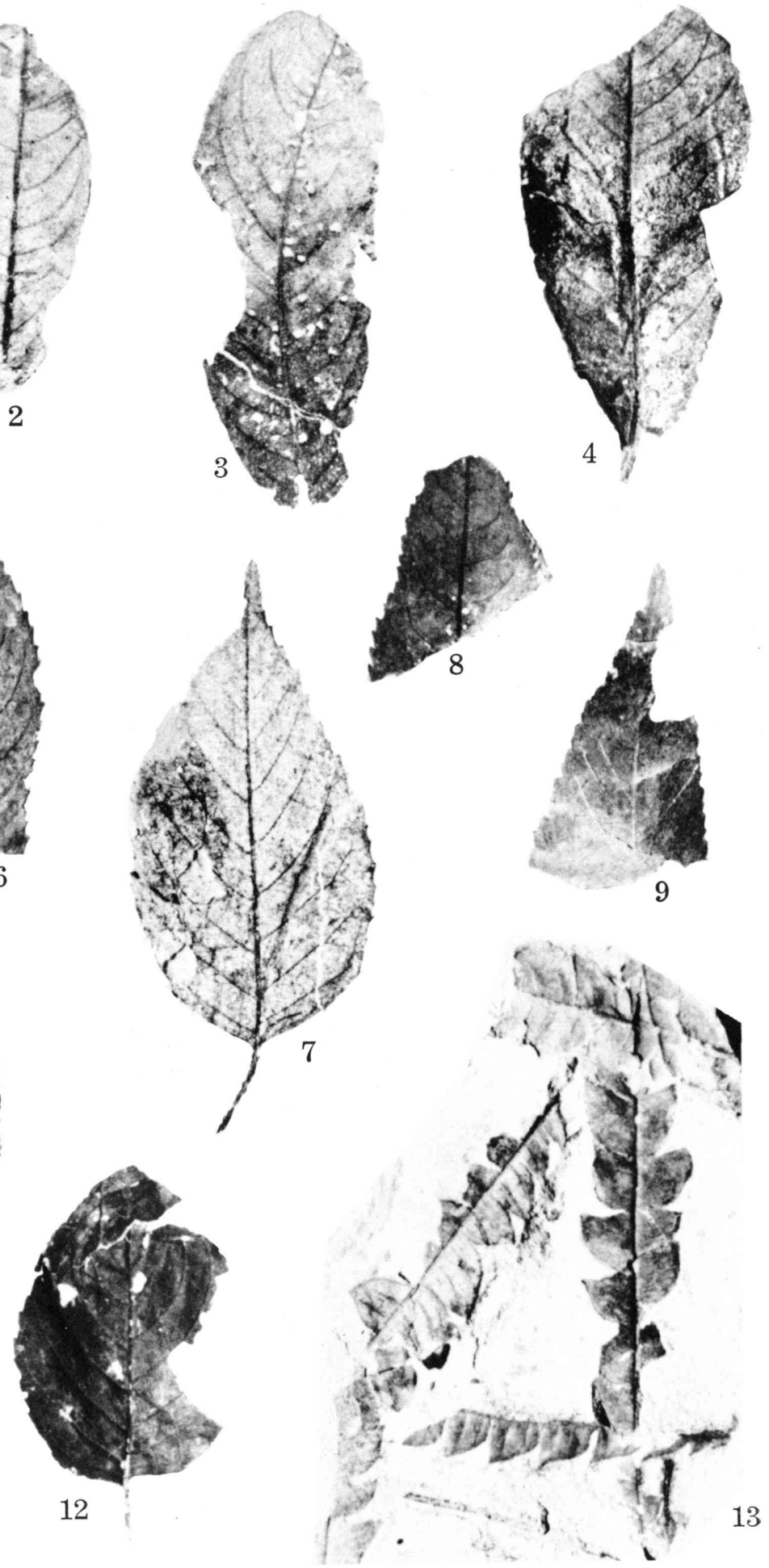

Y. HoJ0: Some Miocene plant fossils from Tottori and Shimane Prefectures 
Platycarya sp.

Pl. 5, Figs. 6, 9

Material: Leaves.

Remarks: Leaf-characters of the present materials have some resemblance to the fossil Platycarya miocenica HU et CHANEY and Carya miocathayensis $\mathrm{HU}$ et CHANEY. However, in leaf-size, the similarity is closer in the former species, which is closely related to the living $P$. strobilaceae SIEB. et ZuCc. growing in Japan, southern Korea and Central China.

Occurrence: Fuganji mudstone Formation; Loc. nos. 2 and 3, Tottori Area.

\section{Family BetUlACEAE}

Alnus miojaponica TANAI

Pl. 6, Figs. 3-8, 12, 14

1955. Alnus miojaponica TanaI. Geol. Surv. Japan Rep. No. 163, Pl. 6, fig. 8.

1963. Alnus miojaponica, TANAI and Suzuki. Tertiary floras of Japan, p. 111, Pl. 5, figs. 6, 7, 11; Pl. 6, fig. 8.

Material: Leaves and cones.

Remarks: The present leaves are safely identified with this species on the basis of the main characters, such as mariginal serration and acuminate apices. This species is commonly found in the Daijima-type flora of Honshu. The modern equivalent of this fossil species is Alnus japonica S. et Z., which is widely distributed in Japan, China and Korea.

Occurrence: Suki Formation; Loc. nos. 1 and 2, Dogo Area.

Alnus sp.

Pl. 5, Figs. 10, 12

Material: Leaves.

Remarks: These leaves are assigned to this genus on the basis of oval-

\section{Explanation of Plate 5}

(All figures in natural size)

Fig. 1. Salix cf. lavateri HeER. ...................................... 21 Takakubo Area, Loc. no. 4.

Figs. 2-5, 8. Juglans japonica TANAI. ............................... 22 Dogo Area, Loc. no. 1.

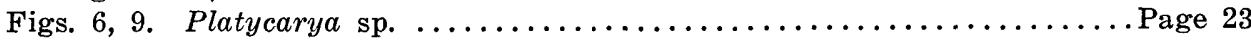
Tottori Area, Loc. no. 2.

Figs. 7, 11. Carpinus miocenica TanAI. ............................. 23 Dogo Area, Loc. no. 1.

Figs. 10, 12. Alnus sp. ........................................ 23

Dogo Area, Loc. no. 2.

Fig. 13. Comptonia naumanni (NАтн.) Huzıoka. .......................... 21 Dogo Area, Loc. no. 3. 
shape of the blade and nervation, but they are not sufficient to discuss their specific identification.

Occurrence: Suki formation; Loc. nos. 1 and 2, Dogo Area.

\section{Carpinus miocenica TANAI}

Pl. 5, Figs. 7, 11

1961. Carpinus miocenica TANAI, TANAI et ONOE. Geol. Surv. Japan Rep. No. 187, pp. 26-27, Pl. 3, fig. 3.

Material: Leaves.

Description: Leaves medium in size, $6.5 \mathrm{~cm}$ long and $3 \mathrm{~cm}$ wide, ovate-oblong in shape: apex acuminate, base mucronate: midrib straight to the apex: margin dupplicated-serrulate.

Remarks: The present specimens are safety identified with this species, which was originally described from the Hoki flora in Ningyo-toge area, Tottori and Okayama Prefectures. This species is closely similar to the modern C. laxiflora Blume, which is widely distributed now in Hokkaido, Honshu, Shikoku and Kyushu.

Occurrence: Suki Formation; Loc. nos. 1 and 2, Dogo Area.

Carpinus cf. miocenica TANAI

Pl. 6, Figs. 9-11, 13, 15; Pl. 7, Figs. 1, 5

Material: Leaves.

Remarks: The main characters preserved in the present leaves resemble those of $C$. miocenica TANAI, which is known from the Middle to Late Miocene of Japan.

Occurrence: Suki and Fuganji mudstone Formations; Loc. nos. 1 and 2, Dogo Area, Loc. nos. 2 and 3, Tottori Area.

\section{Explanation of Plate 6}

(All figures in natural size)

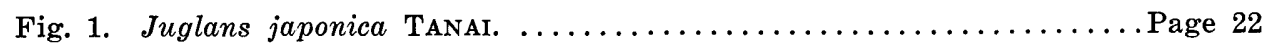
Dogo Area, Loc. no. 1.

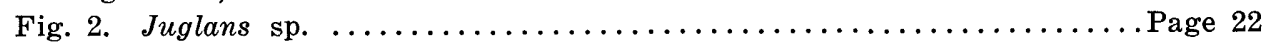
Tottori Area, Loc. no. 2.

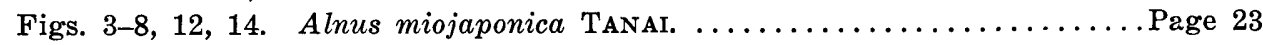
Dogo Area, Loc. no. 2.

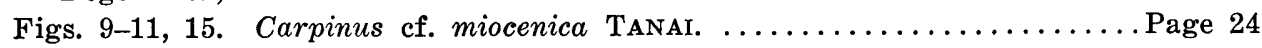
Dogo Area, Loc. no. 1.

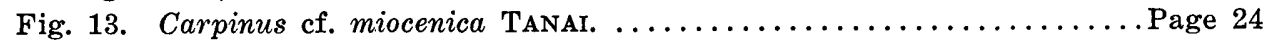
Tottori Area, Loc. no. 3. 

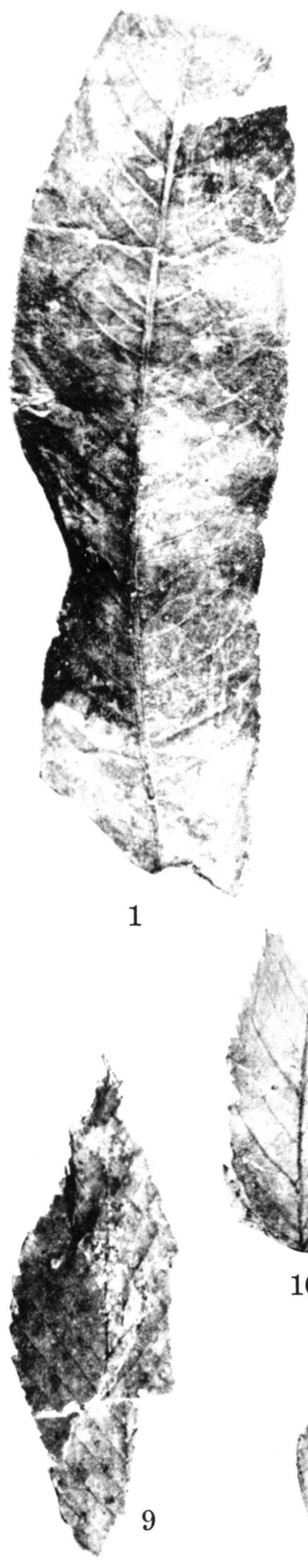
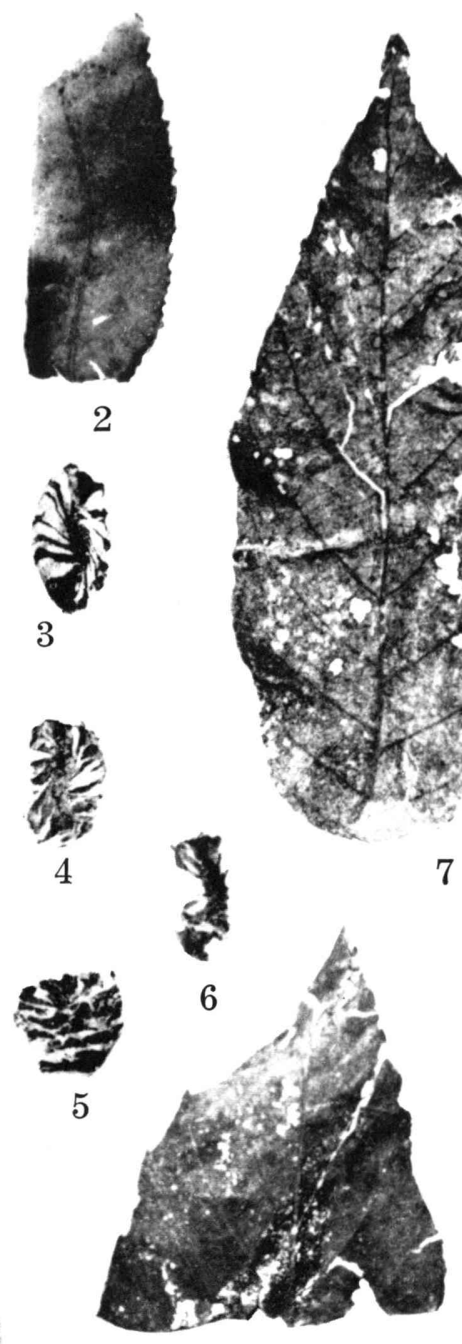

12

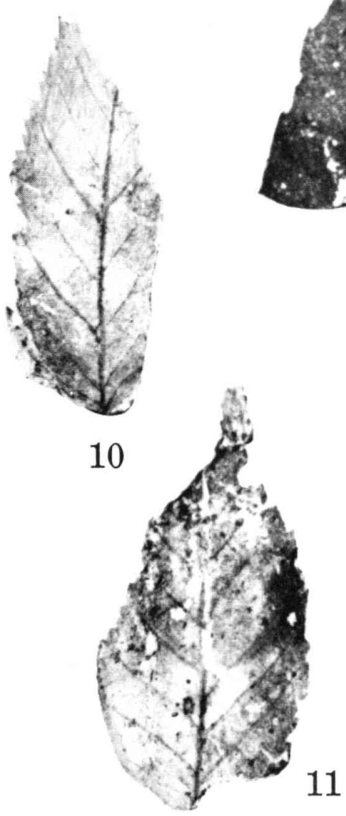

13
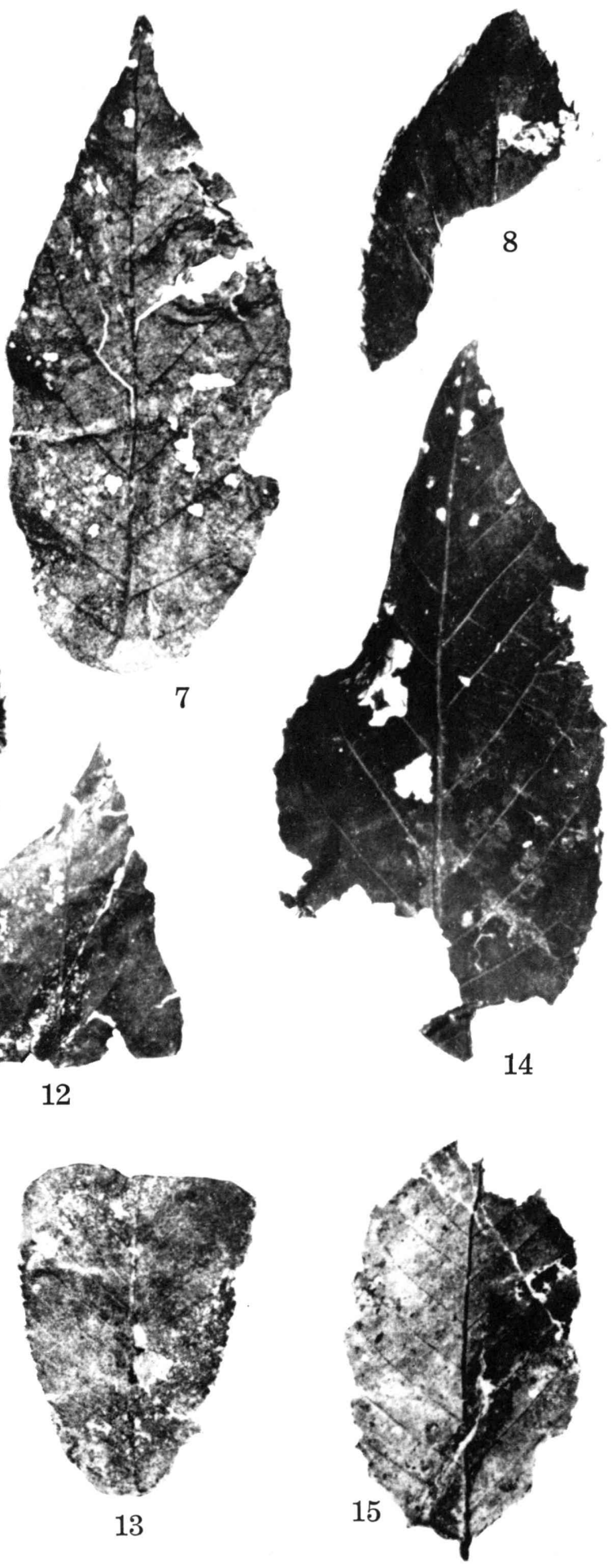

Y. HoJo: Some Miocene plant fossils from Tottori and Shimane Prefectures 

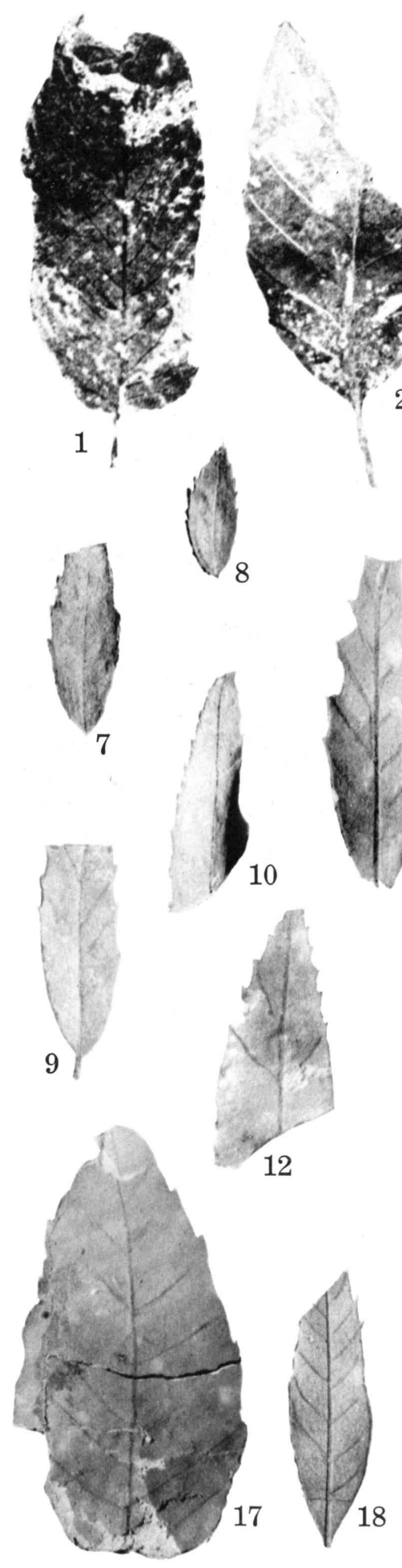
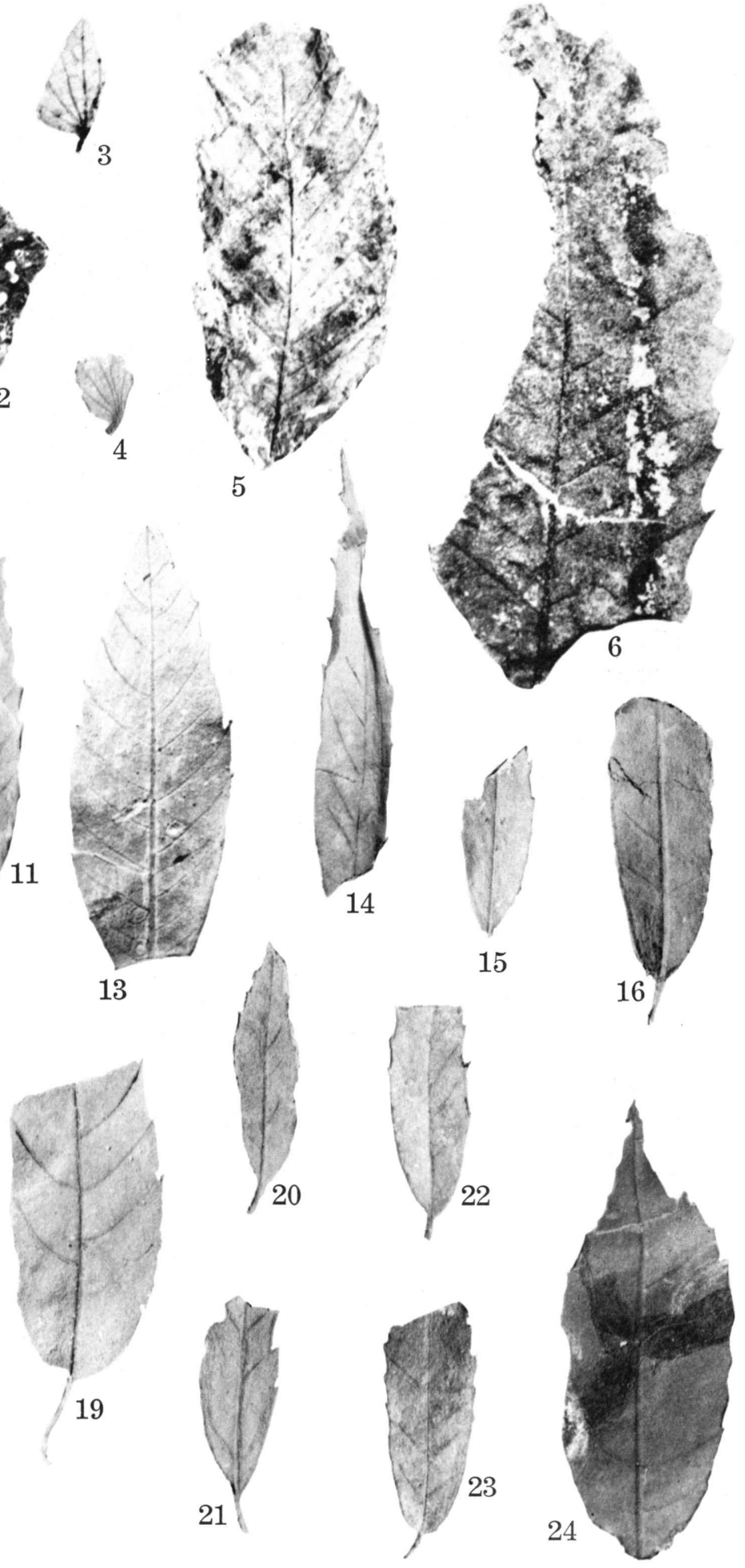

Y. HoJo: Some Miocene plant fossils from Tottori and Shimane Prefectures 
Carpinus sp.

Pl. 7, Fig. 3

Material: Involucre.

Remarks: The present involucre is assigned to this genus on the basis of main features, but the details are unknown because of poor state of preservation.

Occurrence: Suki Formation; Loc. nos. 1 and 2, Dogo Area.

\title{
Carpinus shimizui TANAI \\ Pl. 7, Fig. 4
}

1955. Carpinus shimizui TanaI. Geol. Surv. Japan Rep. No. 1963, Pl. 5, fig. 22. 1963. Carpinus shimizui, TANAI and SuzukI. Tertiary floras of Japan, pp. 116117, P1. 9, fig. 14.

Material: Involucre.

Remarks: Although the present material is incomplete and the size is small, the important feature of venation is well preserved. The veins radiate and leave the midvein at angles of more than 90 degrees. Accordingly, the present involucre is assigned to this species.

Occurrence: Takakubo coal-bearing Formation; Loc. no. 5, Takakubo Area.

\author{
Family FAGACEAE \\ Castanea sp. \\ Pl. 7, Figs. 2, 6
}

Material: Leaves.

Remarks: The present leaves have some resemblance to Castanea ungeri HEER on the basis of nervation and dentate margin. C. ungeri HEER is closely related to $C$. mollissima BLUME of China.

Occurrence: Fuganji mudstone Formation; Loc. nos. 3 and 4, Tottori Area.

\section{Explanation of Plate 7}

(All figures in natural size)

Figs. 1, 5. Carpinus ef. miocenica TANAI. .......................... 24 Tottori Area, Loc. no. 3.

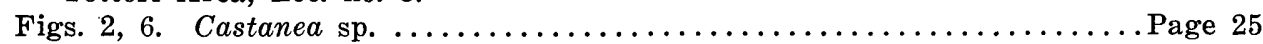
Tottori Area, Loc. no. 3.

Figs. 3. Carpinus sp. ...................................... 25

Dogo Area, Loc. no. 1.

Fig. 4. Carpinus shimizui TanaI. ................................. 25 Takakubo Area, Loc. no. 5.

Figs. 7-16, 18, 20-23. Quercus mandraliscae GaUdin. ................. Page 25 Takakubo Area, Loc. no. 4.

Figs. 17, 24. Quercus nathorsti KRYsht. ........................... 26 Takakubo Area, Loc. no. 4.

Fig. 19. Quercus ef. sinomiocenicum $\mathrm{Hu}$ et Chaney. ....................... 25

Takakubo Area, Loc. no. 3. 


\section{Quercus mandraliscae GAUDIN \\ Pl. 7, Figs. 7-16, 18, 20-23}

1958. Quercus mandraliscae Gaudin. Mem. Gisem. Toscane, p. 33, Pl. 2, fig. 11. 1961. Quercus mandraliscae, TaNaI. Jour. Fac. Sci. Hokkaido Univ., Ser. 4, Vol. 11 , p. 310 , Pl. 12, figs. $4,7$.

Material: Leaves.

Remarks: Although the whole outline of each specimen is unknown, the remarkable features, such as linear-lanceolate shape, very long acuminated apex, marginal serration and nervation, lead to the conclusion that the present specimens are safely identified with Quercus mandraliscae GAUDIN. This species is one of the most common fossil oaks in the Miocene floras of Japan and a representative of the Daijima-type flora. This fossil species has resemblance to modern Q. longinux HAYATA, which is growing at the altitudes of $800 \mathrm{~m}$ to $1400 \mathrm{~m}$ in Formosa and to modern $Q$. myrsinaefolia BLUME, a common tree in the warmer regions of Japan.

Occurrence: Takakubo coal-bearing Formation; Loc. no. 4, Takakubo Area.

\section{Quercus cf. sinomiocenicum HU et CHANEY}

Pl. 7, Fig. 19

Material: Leaf.

Remarks: Only one specimen is obtained from Takakubo coal-bearing Formation. It has some resemblance to Quercus sinomiocenicum on the basis of the leaf-characters. This specimen is also similar to the leaves of living Q. acutissima CARR. which grows in Japan and China.

Occurrence: Takakubo coal-bearing Formation; Loc. no. 3, Takakubo Area.

\section{Quercus nathorsti KRYSHT.}

Pl. 7, Figs. 17, 24

Material: Leaves.

Remarks: The present materials are safely referred to this species by the main leaf-characters. They are closely similar to the leaves of modern Quercus glauca THUNB, growing in the warmer regions of Japan, extending to Formosa and China. This fossil species is commonly found in the Middle Miocene floras in Japan, and is a representative of the Daijima-type flora.

Occurrence: Takakubo coal-bearing Formation; Loc. no. 4, Takakubo Area.

\section{Family UlmaceaE}

Ulmus protojaponica TANAI et ONOE

Pl. 8, Figs. 1, 2, 4

1961. Ulmus protojaponica TANAI et ONOE. Geol. Surv. Japan Rep. No. 187, p. 38, Pl. 10, figs. 2, 5. 
1961. Ulmus protojaponica, TANAI. Jour. Fac. Sci. Hokkaido Univ. Ser. 4, Vol. 11, p. 319, Pl. 17, fig. 4; Pl. 18, fig. 10.

Material: Leaves.

Remarks: Principal leaf-characters assign the present materials to this species, which was originally described from Hoki flora in Tottori and Okayama Prefectures by TANAI and ONOE. The modern equivalent, Ulmus japonica NAKAI, is one of the most common elms in northern Japan.

Occurrence: Fuganji mudstone Formation; Loc. nos. 2, and 3, Tottori Area.

\section{Zelkova ungeri (ETT.) Kovats \\ Pl. 8, Figs. 3, 5-16}

1956. Zelkova ungeri (Етт.) Kovats. Arb. Geol. Ges. Ungarn, Bd. 1, p. 27, Pl. 5, figs. 1-12; Pl. figs. 1-6.

1961. Zelkova ungeri, TANAI. Jour. Fac. Sci. Hokkaido Univ. Ser. 4, Vol. 11, p. 322, Pl. 18, figs. 1-4, 6-9, 11.

1963. Zelkova ungeri, HuzioKa. Tertiary floras of Japan, p. 199, Pl. 32, figs. 1-3; Matsuo, p. 237, Pl. 47, figs. 6-8.

\section{Material: Leaves.}

Remarks: The present leaves are variable in size and shape. Some of them have a closer resemblance to the fossil leaves of Zelkova praelonga (UNGER) BERGER, but the specific difference between $Z$. ungeri and $Z$. praelonga is indistinct. In 1961, TANAI remarked that the difference between both the fossil species gradually diminishes and they are unseparable from each other. I agree to his opinion. This species is closely similar to Z. serrata MAKINo, living in the temperate zone of Japan, China and Korea.

Occurrence: Fuganji mudstone Formation; Loc. no. 2, Tottori Area, Takakubo coal-bearing Formation; Loc. nos. 3 and 4, Takakubo Area.

\section{Family HeMispermaCEAE}

Stephania matsushitai HoJo sp. nov.

Pl. 8, Fig. 21

Material: Seed.

Description: Seed obovate in shape, $7 \mathrm{~mm}$ long and $5 \mathrm{~mm}$ wide in size. Coat relatively thick and horseshoe-shaped with 26 crenulations. A central pore very small and faint.

Remarks: Only a single specimen was examined. It safely belongs to this genus on the basis of the features such as small and faint pore and horseshoeshaped thick margin.

MIKI (1941) reported the fossil Stephania dielsiana WU from the Pliocene Pinus trifolia bed (Jap. Jour. Bot., Vol. 11, pp. 237-303), but in comparison with the features of his species, the present seed has a larger number of crenulations and smaller and fainter central pore. Accordingly, the writer discriminates this seed as a new species, $S$. matsushitai, which is named in honour of Professor 
Emeritus Hisamichi Matsushita. Living species of this genus $S$. japonica Miers is liana of everygreen arbor, growing near the seaside in Japan.

Occurrence: Takakubo coal-bearing Formation; Loc. no. 1, Takakubo Area.

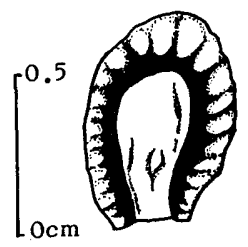

Fig. 4. Stephania matsushitai HoJo sp. nov.

\section{Family HAMAMELIDACEAE}

\section{Liquidamber miocenica $\mathrm{HU}$ et CHANEY}

Pl. 8, Fig. 18; Pl. 9, Figs. 10, 11

1940. Liquidamber miocenica HU et Chaney. Palaeont. Sin. N.S.A. No. 1, p. 46, P1. 23, figs. 1, 2.

1963. Liquidamber miocenica, TANAI and SUzUki. Tertiary floras of Japan, p. 128, Pl. 23, figs. 6, 8, 11; Huzioka, p. 204, Pl. 34, fig. 7, Pl. 35, fig. 1; Matsuo, p. 239, Pl. 52, figs. 4,5 .

Material: Leaves.

Remarles: Fossil leaves and fruits of this kind from Japan have been called Liquidamber formosana HANCE or L. mioformosana TANAI. In 1961, TANAI, Huzioka and MATsuo assigned the name used by Hu and CHANEY to indicate their status as a Tertiary plant. This species is closely similar to the living $L$. formosana HANCE which grows now in Formosa and southwestern China.

Occurrence: Fuganji mudstone formation; Loc. no. 2, Tottori Area, Takakubo coal-bearing formation; Loc. no. 3, Takakubo Area.

\section{Explanation of Plate 8}

(All figures in natural size)

Figs. 1, 2, 4. Ulmus protojaponica TANAI et ONOE. ................ Page 26 Tottori Area, Figs. 1, 2, Loc. no. 3; Fig. 4, Loc. no. 2.

Figs. 3, 5-14. Zelkova ungeri (Eтт.) Kovats. .................... Page 26 Tottori Area, Loc. no. 2.

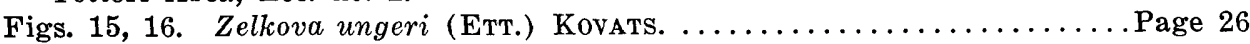
Takakubo Area, Loc. no. 3.

Fig. 17. Entada cf. mioformosana TanaI. ..................... Page 26

Tottori Area, Loc. no. 2.

Fig. 18. Liquidamber miocenica $\mathrm{Hu}$ et Chaney. .......................... 29 Tottori Area, Loc. no. 2.

Figs. 19, 22. Machilus ugoana Huzioka. ........................... 27

Dogo Area, Loc. no. 1.

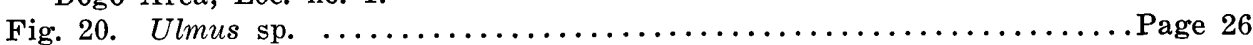

Tottori Area, Loc. no. 2.

Fig. 21. Stephania matsushitai HoJo sp. nov. ................... Page 27

Takakubo Area, Loc. no. 1. 


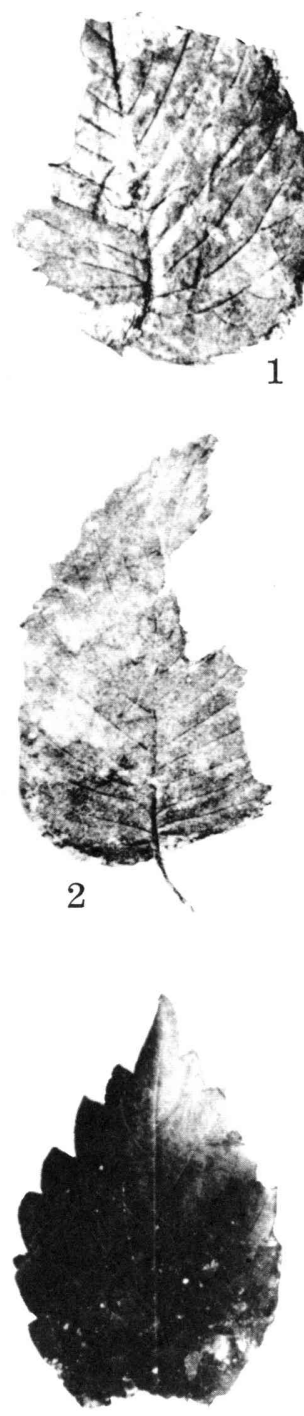

11
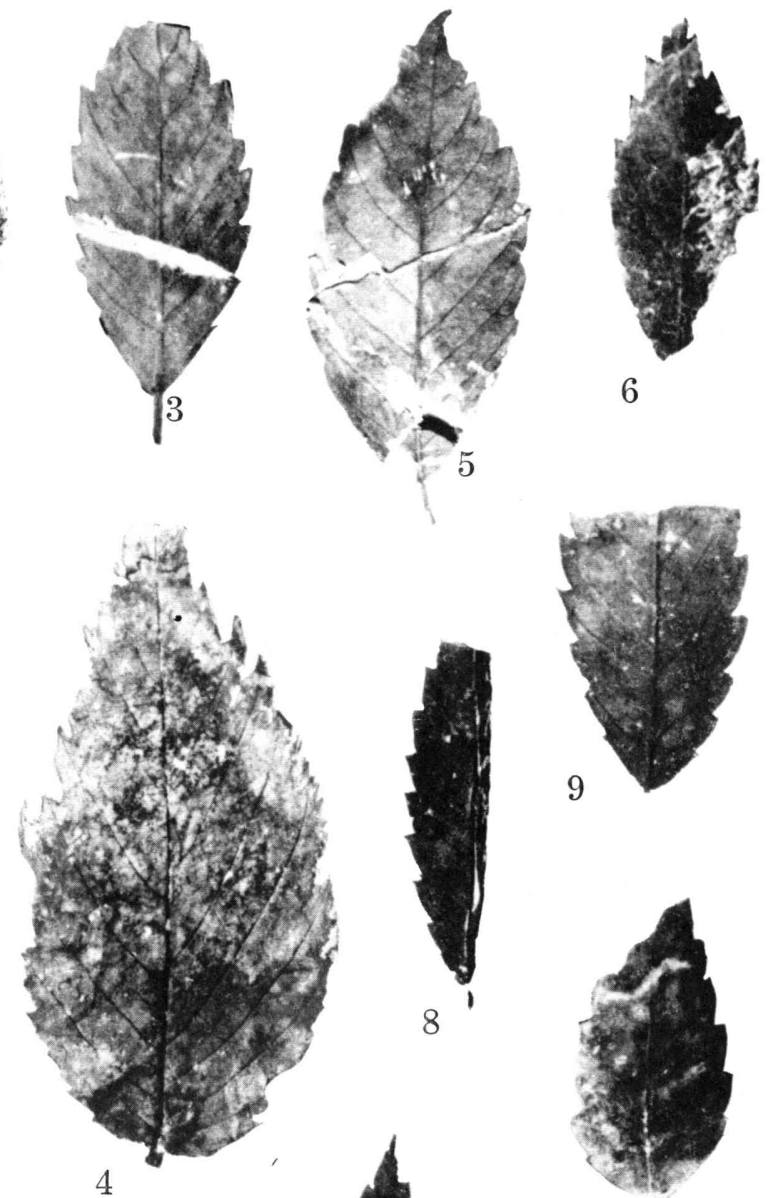

6
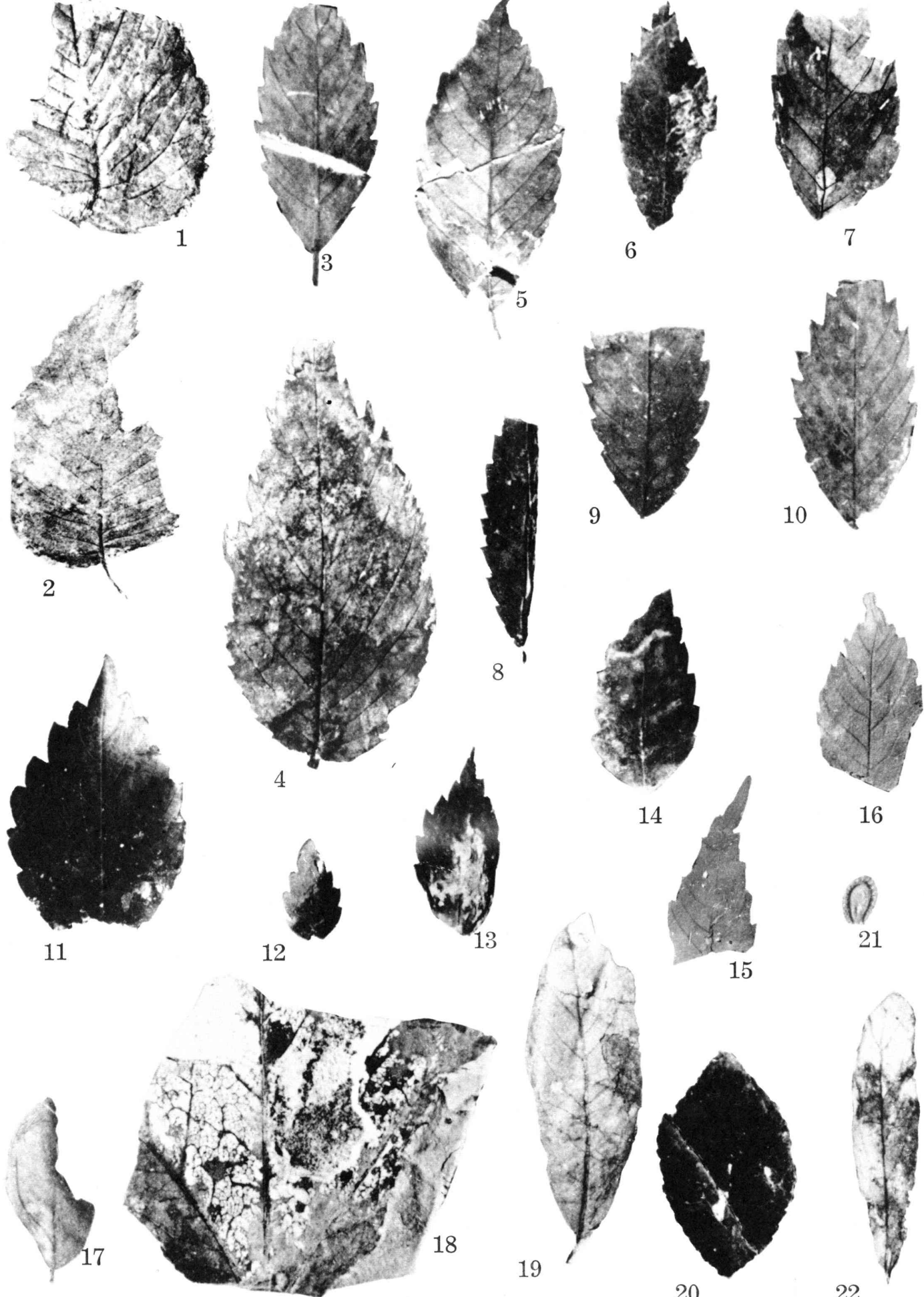

14
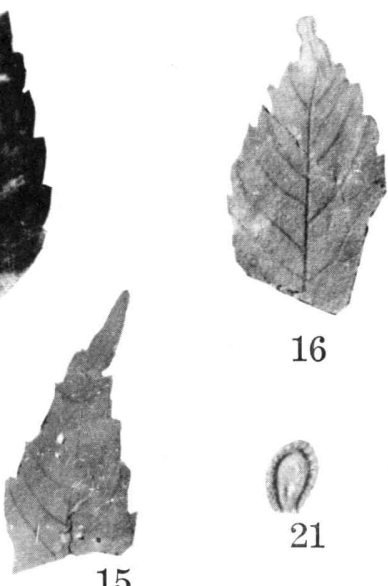

(1)
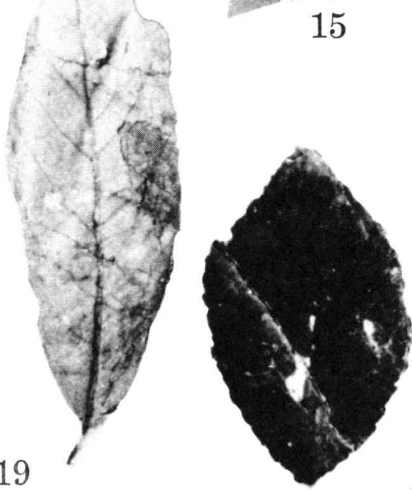

20

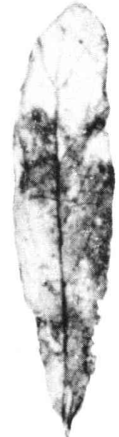

Y. HоJ0: Some Miocene plant fossils from Tottori and Shimane Prefectures 

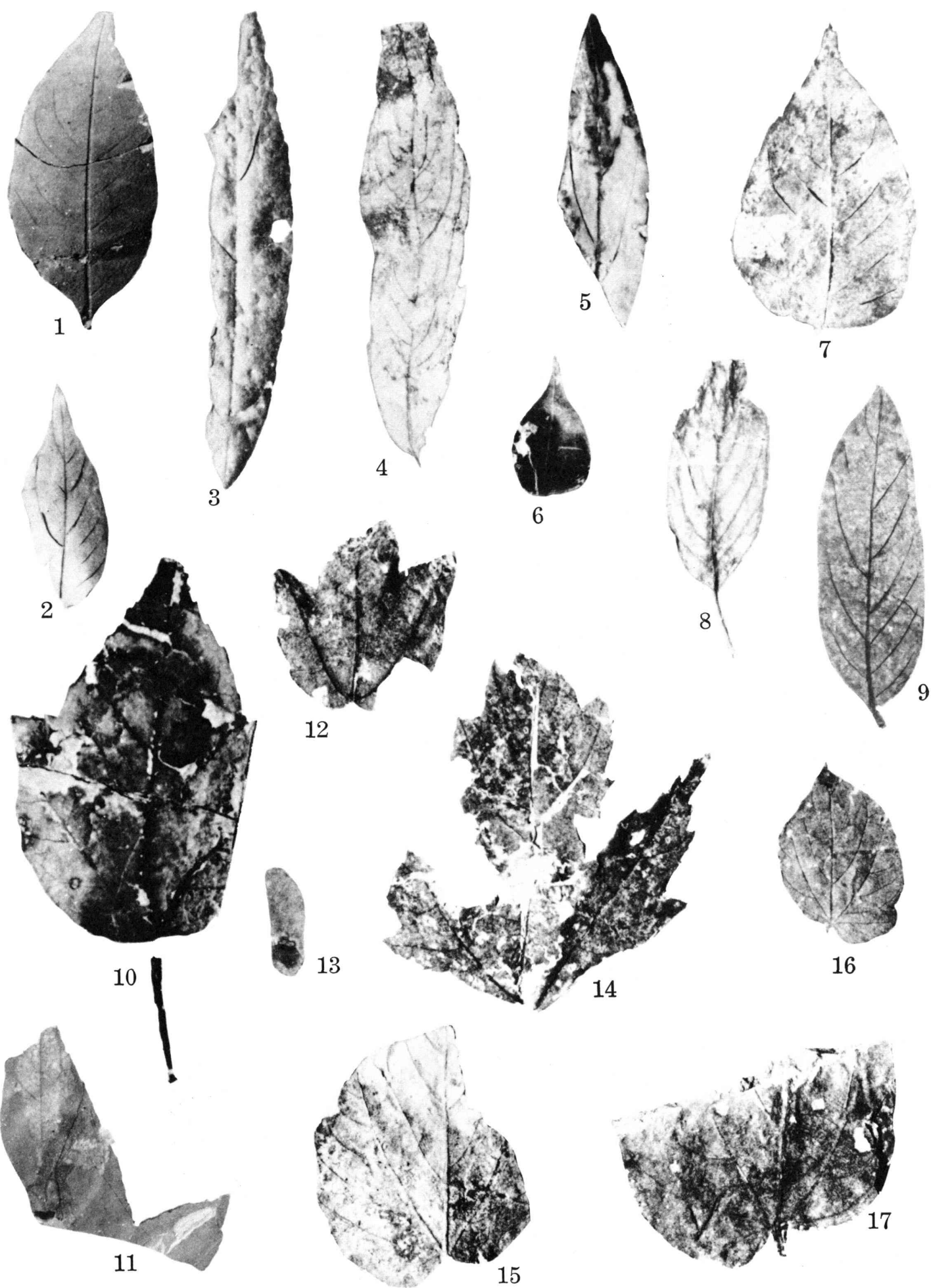

Y. Hojo: Some Miocene plant fossils from Tottori and Shimane Prefectures 


\section{Family LAURACEAE \\ Lindera gaudini (NATH.) TANAI}

Pl. 9, Fig. 1

1961. Lindera gaudini (NATH.) TanAI. Jour. Fac. Sci. Hokkaido Univ., Ser. 4, Vol. 11, p. 335, Pl. 22, fig. 1.

Material: Leaf.

Remarks: TANAI revised NATHORST's species (Lauriphyllum gaudini NATH., Palaeont. Abh. Bd. 4, No. 3, p. 9, Pl. 2, fig. 6) on the basis of foliar shape and nervation, and assigned it to Lindera.

This species is comparable with the living Lindera glauca (S. et Z.) BLUME, which is distributed in central and western Honshu, Shikoku and Kyushu, extending to China, Formosa and Korea.

Occurrence: Takakubo coal-bearing Formation; Loc. no. 5, Takakubo Area.

Machilus ugoana HuzıoKA

Pl. 8, Figs. 19, 22; Pl. 9, Figs. 3-5, 8

1961. Machilus ugoana HuZioka. TANaI, Jour. Fac. Sci. Hokkaido Univ., Ser., 4, Vol. 11, p. 336, Pl. 22, fig. 3.

1963. Machilus ugoana, HUzIOKA. Tertiary floras of Japan, p. 203, Pl. 34, figs. $4-6$; Pl. 40, fig. 7 .

\section{Explanation of Plate 9}

(All figures in natural size)

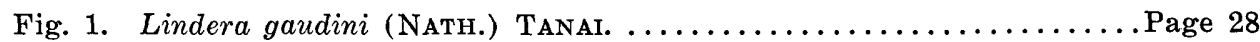
Takakubo Area, Loc. no. 5.

Figs. 2, 6. Wistaria sp. ...................................... 29 Tottori Area, Loc. no. 2.

Figs. 3, 5. Machilus ugoana Huzioka. .............................. 28 Tottori Area, Loc. no. 2.

Figs. 4, 8. Machilus ugoana Huzioka. .............................. 28 Dogo Area, Loc. no. 1.

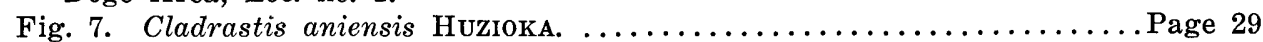
Tottori Area, Loc. no. 3.

Fig. 9. Sapindus miocenica Huzioka. .............................. 30 Tottori Area, Loc. no. 3.

Fig. 10. Liquidamber miocenica $\mathrm{Hu}$ et Chaney. ........................ 27 Tottori Area, Loc. no. 2.

Fig. 11. Liquidamber miocenica $\mathrm{Hu}$ et Chaney. .................. Page 27 Takakubo Area, Loc. no. 3.

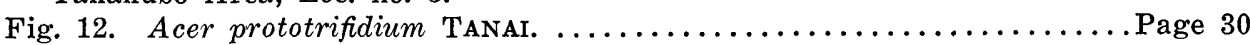
Dogo Area, Loc. no. 1.

Fig. 13. Acer protojaponicum TANAI et ONOE. ..................... Page 30 Tottori Area, Loc. no. 2.

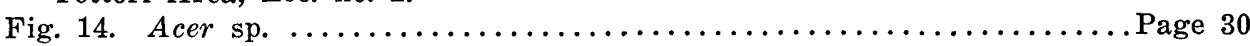
Dogo Area, Loc. no. 2.

Figs. 15-17. Alangium koyamae (Konno) TanaI. .......................... 31 Tottori Area, Loc. no. 4. 
Material: Leaves.

Remarks: The present fossil leaves are safely referred to this species in foliar shape and nervation. The leaf-characters of this fossil species are closely similar to those of the living Machilus japonica $\mathrm{S}$. et $\mathrm{Z}$. from the warm-temperate forests of eastern Asia.

Occurrence: Suki and Fuganji mudstone Formations; Loc. no. 1, Dogo Area, Loc. no. 2, Tottori Area.

\section{Family Legminosae \\ Cladrastis aniensis HUZIOKA \\ Pl. 9, Fig. 7}

1963. Cladrastis aniensis Huzioka. Tertiary floras of Japan, p. 205, Pl. 35, figs. 5-6.

Material: Leaf.

Description: Leaf ovate, $4.8 \mathrm{~cm}$ wide slightly asymmetrical, apex acute, base broadly rounded. Midrib stout, secondary veins irregularly spaced, curving upward near the margin. Margin entire.

Remarks: Only a single specimen is examined and safely identified with this species. The modern species comparing with this fossil species is C. platycarpa (MAX.) MAKINo, which grows in the warmer regions of Japan and China.

Occurrence: Fuganji mudstone Formation; Loc. no. 3, Tottori Area.

\section{Entada cf. mioformosana TANAI}

Pl. 8, Fig. 17

Material: Leaf.

Remarks: The leaf features observed in the present material such as elliptical foliar shape and entire margin are compared with those of Entada mioformosana TANAI, which is commonly found in the Middle Miocene Daijima-type flora, and is one of the indicators of warm climate at that time. This species is closely similar to the living Entada formosana KaneHIRA in Formosa.

Occurrence: Fuganji mudstone Formation; Loc. no. 2, Tottori Area.

\section{Explanation of Plate 10}

(All figures in natural size)

Figs. 1, 6, 10. Alangium aequalifolium (GoEPP.) KRYShT. et BoRSUK. ......Page 31 Tottori Area, Loc. no. 4.

Fig. 2. Alangium koyamae (KonNo) TanAI. .................................... 31 Takakubo Area, Loc. no. 4.

Figs. 3-5, 7-9. Alangium koyamae (Konno) Tanal. ....................... 31 Tottori Area, Loc... no. 4. 


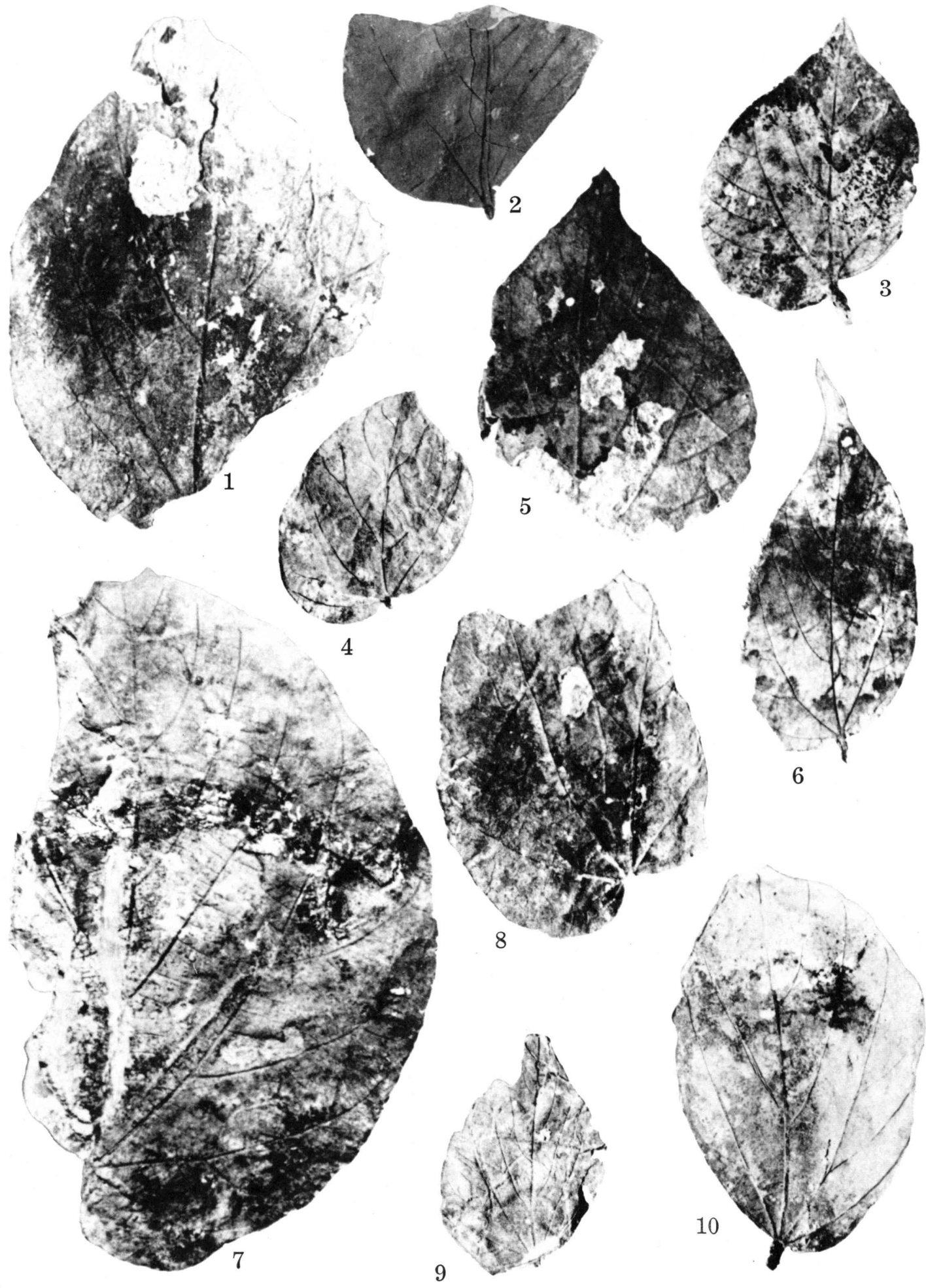

Y. HoJ0: Some Miocene plant fossils from Tottori and Shimane Prefectures 
Wistaria sp.

Pl. 9, Figs. 2, 6

Material: Leaves.

Remarks: The present materials are identical to the leaves of Legminosae in their shape and nervation. The venation in these materials is closely related to that of Wistaria. In Japan, the fossil Wistaria has been called under the name of the living $W$. floribunda DC., but in 1961 TANAI and ONOE referred it to $W$. fallax (NATH.) TANAI et ONOE.

Occurrence: Fuganji mudstone Formation; Loc. no. 2, Tottori Area.

\section{Family SAPINDACEAE}

Sapindus miocenica HUZIoKA

Pl. 9, Fig. 9

1963. Sapindus miocenica HuzioKa. Tertiary floras of Japan, p. 210, Pl. 37, fig. 6, Matsuo, p. 241, Pl. 52, fig. 1.

Material: Leaf.

Description: Foliar shape, linear-oblong, $4.8 \mathrm{~cm}$ long and $1.7 \mathrm{~cm}$ wide. Apex acuminate, base obtuse. Midrib stout in below, secondary veins curving up, diverging from the midrib at the angles of about 30 degrees. Margin entire.

Remarks: This species resembles two modern species from warmer regions of eastern Asia, Sapindus mukorossi GaERTN. and S. delavayi (FR.) RADLK.

Occurrence: Fuganji mudstone Formation; Loc. no. 3, Tottori Area.

Family ACERACEAE

Acer protojaponicum TANAI et ONOE

Pl. 9, Fig. 13

1959. Acer protojaponicum TANAI et ONoE. Bull. Geol. Surv. Japan, Vol. 11, no. 4, p. 281, Pl. 6, figs. 5, 7, 8 .

Material: Samara.

Remarks: This species was first shown by TANAI (1955) without description. The present material is safely referred to this species by the features such as small size and ellipsoidal seed. The modern species corresponding to this fossil species is $A$. japonicum ThunB. growing in Hokkaido and Honshu.

Occurrence: Fuganji mudstone Formation; Loc. no. 2, Tottori Area.

\section{Acer prototrifidium TANAI}

Pl. 9, Fig. 12

1952. Acer prototrifidium Tanal. Trans. Proc. Palaeont. Soc. Japan, N.S., No. 8, p. 234, Pl. 22, fig. 13.

1961. Acer prototrifidium, TaNaI. Jour. Fac. Sci. Hokkaido Univ. Ser. 4, Vol. 11, 
p. 364, Pl. 25, fig. 2.

1971. Acer prototrifidium, Hojo. Prof. H. Matsushita Memorial Volume, p. 152, Pl. 11, figs. 2-5; Pl. 12, figs. 1-2 (in Japanese).

Material: Leaf.

Remarks: The present specimen is characterized by the tri-lobed shape. Among the tri-lobed Aceraceae, it is safely referred to this species on the basis of nervation.

Occurrence: Suki Formation; Loc. no. 1, Dogo Area.

Acer sp.

Pl. 9, Fig. 14

Material: Leaf.

Remarks: The present leaf is characterized by the tri-lobed shape with coarse marginal teeth.

Occurrence: Suki Formation; Loc. no. 2, Dogo Area.

\section{Family Alangiaceae}

Alangium aequalifolium (GoEPP.) KRYSHT. et BoRSUK

Pl. 10, Figs. 1, 6, 10

1939. Alangium aequalifolium (GoEPP.) KrYSht. et Borsuk. Prob. Palaeont. No. 5, p. 390, Pl. 5, figs. 1-8; Pl. 6, fig. 12.

1961. Alangium aequalifolium, TANAI. Jour. Fac. Sci. Hokkaido Univ., Ser. 4, Vol. 11, p. 371, Pl. 30, fig. 1; Pl. 31, fig. 9.

Material: Leaves.

Description: Leaves orbicular to ovate, strongly asymmetrical, variable in size, $2.5-6 \mathrm{~cm}$ long and $2-6 \mathrm{~cm}$ wide. Apex acute, base obliquely slightly cordate. Margin entire. Primary veins 5-palmate, midrib slightly arched, basal primary pair slender, arising along the margin, upper lateral primary pair diverging from the midrib at the angles of about 30 degrees with 4 or 5 abaxial branches. Secondary veins 3 or 4 pairs, alternate, parallel to the upper lateral primaries.

Remarks: Although the leaf-size of the present materials is somewhat smaller than the known species of this kind, they are safely identified with this species by main features. The present materials have some resemblance to the fossil A. koyamae (KonNo) TANAI, but they are clearly distinguished from the latter species by their foliar shape.

Occurrence: Fuganji mudstone Formation; Loc. no. 4, Tottori Area.

Alangium koyamae (KoNNo) TANAI

Pl. 9, Figs. 15-17; Pl. 10, Figs. 2-5, 7-9

1961. Alangium koyamae (Konno) TanaI. Jour. Fac. Sci. Hokkaido Univ., Ser. 4, Vol. 11, p. 373, Pl. 30, figs. 2, 4. 
Material: Leaves.

Remarks: TANAI (1961) revised KonNo's species (Dolichites koyamai KonNo, 1931), assigning it to Alangium and comparing it with the modern $A$. chinense REHD.

Occurrence: Fuganji mudstone Formation; Loc. nos. 2 and 4, Tottori Area, Takakubo coal-bearing Formation; Loc. no. 4, Takakubo Area.

\section{Conclusion}

A large number of fossil species have been collected from the Miocene formations distributed sporadically in three separate areas, Takakubo lignite field, Fuganji in Tottori Prefecture and Dogo in Oki-island.

The floral species identified with certainty and their living equivalents in each area are listed up respectively in Table 2-4. For the convenience of presentation, the assemblage of fossil flora and its living equivalents in three areas is called the Takakubo-, Fuganji-, and Dogo-flora, respectively. Considering the specific assemblage, these three floras were deciduous tree, which grew in montaineous high-land, and they are, as a whole, referred to the Daijima-type flora. These three floras are hard to be distinguished by their components from each other. However, if the geographical distributions of the living equivalents of each flora are considered, the living components of the Takakubo flora is referred to as subtropic-warm facies in Asia and those of the Fuganji flora as warm-cold one. Furthermore, the exact stratigraphical relationship between two areas leads to an assumption that it may be more appropriate that the Fuganji flora is correlated to Aniai-, Mitoku-, and Shinjo-type flora rather than to the Takakubo- or Daijima-type.

\section{Reference}

Berger, W. (1955) : Nachträge zue altpliozänen Flora der Congerien schichten von Brunn-Vösendorf bei Wien. Paleontogr. Bd. 97, Abt. B., 74-80.

Chaney, R. W. (1940): Tertiary forests and continental history. Bull. Geol. Soc. America, 51, 481-486.

(1951): A revision of fossil Sequoia and Taxodium in Western North America based on the recent discovery of Metasequoia. Trans. American Philos. Soc., New Ser., 40, (172).

(1952): Conifer dominant in the Middle Tertiary of the John Day Basin, Oregon. Palaeobot., 1, 105-113.

Endo, S. (1936): New fossil species of Sequoia from the Far-East. Proc. Imp. Acad. Tokyo, 12, (6), 172-175.

(1950) : On the fossil Carpinus from Japan and Korea. Short Papers, Inst. Geol. Palaeont. Tohoku Univ. Sendai, 2, 51-57.

and Morita, H. (1932): Notes on the genera Comptoniphyllum and Liquidamber. Sci. Rep. Tohoku Imp. Univ., 2nd Ser., 15, (2), 41-53.

Gaudin, C. T. et Strozzi, C. (1958): Memoire sur quelques gisements de feuilles fossiles de la Toscane. Neue Denks. allig. Schweiz. Ges. Naturf., 16.

HuziokA, K. (1943): Notes on some Tertiary plants from Tyosen I. Jour. Fac. Sci. Hokkaido Imp. Univ., [IV], 7, (1), 118-141.

(1943): On the fossil involcures of Ostrya and Carpinus from the Miocene de- 
posits of Hokkaido and Tyosen. (in Japanese) Jour. Geol. Soc., Japan, 150, (602), 285-295.

HUziokA, K. (1951) : Notes on some Tertiary plants from Tyosen II. Trans. Proc. Palaeont. Soc. Japan, N. S., (3), 67-74.

(1954): Notes on some Tertiary plants from Tyosen III. Trans. Proc. Palaeont. Soc. Japan, N. S. (13), 117-123.

(1954) : Notes on some Tertiary plants from Tyosen IV. Trans. Proc. Palaeont. Soc. Japan, N. S., (15), 195-200.

(1955) : Notes on some Tertiary plants from Tyosen V. Trans. Proc. Palaeont. Soc. Japan, N. S., (19), 59-64.

(1961): A new Palaeogene species of the genus Comptonia from Joban coal-field, with referrence to the stratigraphical consideration on the Tertiary Comptonia in northeastern Japan. Jour. Min. Coll. Akita Univ., [A]. 1, (1), 60-68.

(1963) : The Utto flora of northern Honshu. Tertiary floras of Japan, 153-216, Geol. Surv. Japan.

and SuzukI, K. (1954) : The fiora of the Shiotsubo formation of Aizu lignite-field, Fukushima Prefecture. Trans. Proc. Palaeont. Soc. Japan, N. S., (14), 133-142.

Hu, H. and Chaney, R. W. (1938): A Miocene flora from Shantung Province, China. Palaeont. Sinica. new series A, (1).

IshidA, S. (1970): The Noroshi flora of Noto Peninsula, central Japan. Mem. Fac. Sci. Kyoto Univ., [Geol. Min.], 37, (1), 1-112.

KrIShtofovich, A. (1926) : Contribution to the Tertiary flora of Kannonzawa, Province Echigo, Japan. Ann. Rep. Russ. Palaeont. Soc., [6], 1-24.

Matsuo, H. (1963): The Notonakajima flora of Noto Peninsula. Tertiary floras of Japan, 219-43, Geol. Surv. Japan.

MIKI, S. (1941): On the change of flora in eastern Asia since Tertiary period, (I) The clay of lignite beds flora in Japan with special reference to the Pinus trifolia beds in central Honshu. Jap. Jour. Bot., 11, 237-303.

Murayama, M., Ishiki, N. and SaKamoto, T. (1963) : Explanatory text of the geological map of Japan, "TотtoRihoKUBU and TOTTORINANBU", (1/50000). Geol. Surv. Japan.

NishiYama, S. and MiURA, K. (1968): Geological sheet map of Shimane Prefecture, $1: 200,000$, with explanatory text.

OISHI, S. and HUzIOKA, K. (1941) : Studies on Cenozoic plants of Hokkaido and Karafuto, (III) Comptoniphyllum from Hokkaido and Karafuto. Jour. Fac. Sci. Hokkaido Imp. Univ., [IV], 6, (2), 201-204.

TAI, Y. (1959): Miocene microbiostratigraphy of west honshu Japan. Jour. Sci. Hiroshima Univ., [C], 2, (4), 265-395.

TANAI, T. (1953) : Notes on some plant fossils from Ennichi group in Southern Korea (II). Trans. Proc. Palaeont. Soc. Japan, N. S., (9), 1-7.

(1952): Des fossiles vegetaux dans le bassin houiller de Nishitagawa, Prefecture de Yamagata, Japan. Jap. Jour. Geol. Geogr., 22, 119-135.

(1952) : Notes a propos de quelques plantes fossiles dans le groupe d'Ennichi du Coree méridionale (I). Trans. Proc. Palaeont. Soc. Japan, N. S., (8), 231-236. and ONOE, T. (1959): A Miocene flora from the northern parts of the Joban coalfield, Japan. Bull. Geol. Surv. Japan, 10, (4), 261-286.

and (1961): A Mio-Pliocene flora from the Ningyo-toge area on the border between Tottori and Okayama Prefectures, Japan. Geol. Surv. Japan, Rep. 187.

- and SUzUKI, N. (1960): Miocene maples from southwestern Hokkaido, Japan. Jour. Fac. Sci. Hokkaido Univ., 4, 10, (3), 551-570. and - (1963): Miocene floras of southwestern Hokkaido, Japan. Tertiary floras of Japan, 9-149, Geol. Surv. Japan.

(1961): Neogene floral change in Japan. Jour. Fac. Sci. Hokkaido Univ., 4, 11, (2), 119-398.

Totrori PREFeCture (1966) : Explanatory text of the geological map of Tottori Prefecture $(1 / 200,000)$. 
Appendix

Alphabetical list of place names

\begin{tabular}{|c|c|c|c|}
\hline San-in & 山 & Tsunodani & 角 \\
\hline Tottori & 鳥 & Okitani & 沖 \\
\hline Shimane & 島 & Misaka & $\equiv$ \\
\hline Tochimoto & 杤 & Nishitani & 西 \\
\hline Fuganji & 普 含 寺 & Oki & 隠 \\
\hline Okamasu & 岡 & Nakayama & 中 \\
\hline Uba Jinjya & 宇倍神社 & Yatsuo & 八 \\
\hline Miyanoshita & 宮 ノ下 & Gongenbara & 権 現 \\
\hline Kumoyama & 雲 山 & Suki & 周 \\
\hline Takakubo & 高 & Ochi & 隠 \\
\hline
\end{tabular}

